DEC 71998

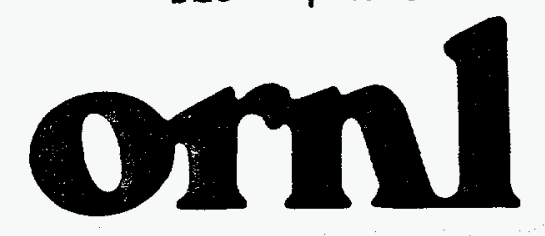

OAK RIDGE NATIONAL LABORATORY

LOCKHEED MARTU
ORNL Master Copy

\section{RECEIVED}

JAN 281999

OSTI

Results of the Independent Radiological

Verification Survey of

Remediation at Building 31, Former Linde Uranium Refinery, Tonawanda, New York (LI001V)
S. P. McKenzie

M. S. Uziel 
This report has been reproduced directly from the best available copy.

Available to DOE and DOE contractors from the Office of Scientific and Technical Information, P.O. Box 62, Oak Ridge, TN 37831; prices available from $423-576-8401$.

Available to the public from the National Technical Information Service, U.S. Department of Commerce, 5285 Port Royal Rd., Springfield, VA 22161.

This report was prepared as an account of work sponsored by an agency of the United States Government. Neither the United States Government nor any agency thereof, nor any of their employees, makes any warranty, express or implied, or assumes any legal liability or responsibility for the accuracy, completeness, or usefulness of any information, apparatus, product, or process disclosed, or respresents that its use would not infringe privately owned rights. Reference herein to any specific commercial product, process, or service by trade name, trademark, manufacturer, or otherwise, does not necessarily constitute or imply its endorsement, recommendation, or favoring by the United States Government or any agency thereof. The views and opinions of authors expressed herein do not necessarily state or reflect those of the United States Government or any agency thereof. 


\section{DISCLAIMER}

Portions of this document may be illegible in electronic image products. Images are produced from the best available original document. 
Prepared for the U.S. ARMY CORPS OF ENGINEERS, Buffalo District (Budget and Reporting Code 43WM1 1202; Agency Code DAG)

\section{Results of the Independent Radiological Verification Survey of Remediation at Building 31, Former Linde Uranium Refinery, Tonawanda, New York (LI001V)}

S. P. McKenzie and M. S. Uziel

Date Issued-November 1998

Investigation Team

R. D. Foley - Measurement Applications and Development Manager S. P. McKenzie - Survey Team Leader

\begin{tabular}{|c|c|}
\hline $\begin{array}{l}\text { G. H. Cofer } \\
\text { R. L. Coleman } \\
\text { R. C. Gosslee } \\
\text { D. D. McKinney* } \\
\text { M. E. Murray } \\
\text { V.P. Patania }\end{array}$ & $\begin{array}{l}\text { D. E. Rice } \\
\text { D. A. Roberts } \\
\text { R. E. Rodriguez } \\
\text { D. A. Rose } \\
\text { M. A. Rose } \\
\text { W. Winton }\end{array}$ \\
\hline & \\
\hline
\end{tabular}

-Midwest Technical, Inc.

Work performed by the MEASUREMENT APPLICATIONS AND DEVELOPMENT GROUP LIFE SCIENCES DIVISION

Prepared by the

OAK RIDGE NATIONAL LABORATORY

Oak Ridge, Tennessee 37831-6285

managed by

LOCKHEED MARTIN ENERGY RESEARCH CORP.

for the

U.S. DEPARTMENT OF ENERGY

under contract DE-ACOS-96OR22464 
$-$ 


\section{CONTENTS}

FIGURES $\ldots \ldots \ldots \ldots \ldots \ldots \ldots \ldots \ldots \ldots \ldots \ldots \ldots \ldots \ldots \ldots \ldots \ldots \ldots \ldots$

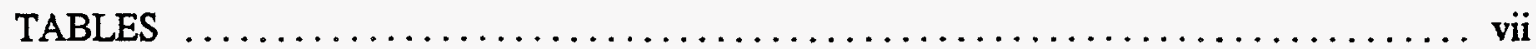

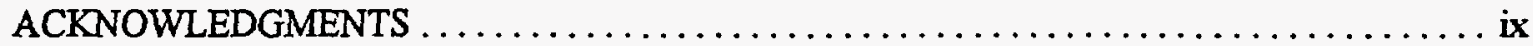

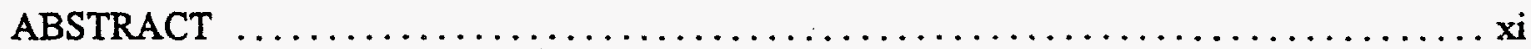

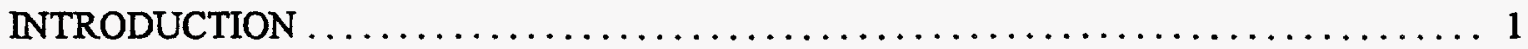

SCOPE OF THE INVESTIGATION $\ldots \ldots \ldots \ldots \ldots \ldots \ldots \ldots \ldots \ldots \ldots \ldots \ldots \ldots \ldots \ldots \ldots$

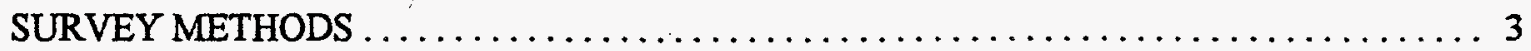

VERIFICATION SURVEY RESULTS $\ldots \ldots \ldots \ldots \ldots \ldots \ldots \ldots \ldots \ldots \ldots \ldots \ldots \ldots \ldots \ldots \ldots \ldots \ldots$

GAMMA AND ALPHA RADIATION LEVELS $\ldots \ldots \ldots \ldots \ldots \ldots \ldots \ldots \ldots \ldots \ldots$

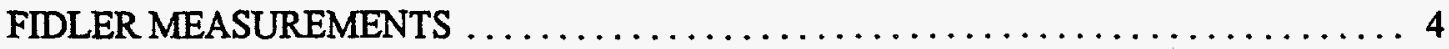

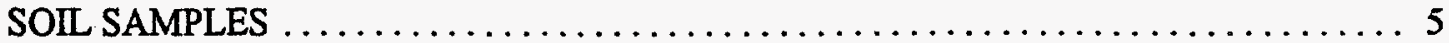

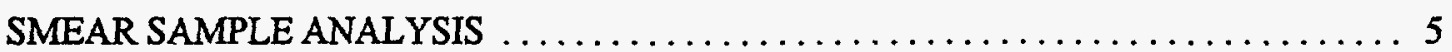

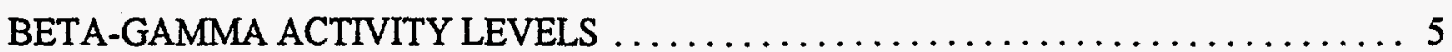

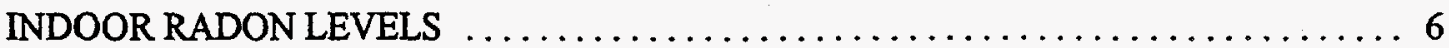

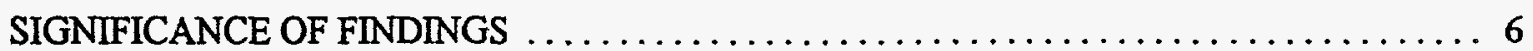

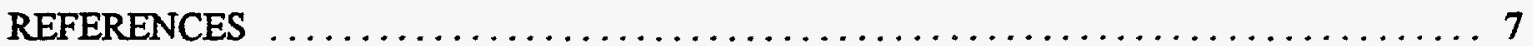


. 


\section{FIGURES}

1 Diagram showing general location of the former Linde site in

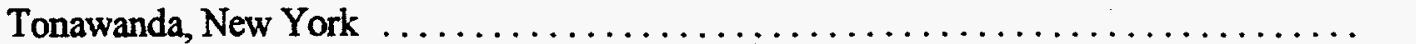

2 Diagram showing general location of Building 31 , at the former Linde site, Tonawanda, New York

3 Diagram showing first floor FIDLER measurements at

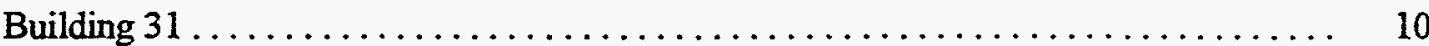

4 Diagram showing second floor FIDLER measurements at Building 31

5 Diagram showing location of biased soil samples collected underneath the first floor at Building 31

6 Diagram showing first floor smear sample locations at Building 31

7 Diagram showing second floor smear sample locations at Building 31

8 Diagram showing 7-day radon sampling locations at Building 31 



\section{TABLES}

1 Applicable guidelines for protection against radiation

2 Background radiation levels and concentrations of selected radionuclides in soil near Tonawanda, New York .

3 Concentrations of radionuclides in soil samples, Building 31, former Linde Uranium Refinery, Tonawanda, New York

4 Transferable alpha and beta-gamma measurements at Building 31, former Linde Uranium Refinery, Tonawanda, New York

5 Data from surveys of individual rooms during verification at Building 31, former Linde Uranium Refinery, Tonawanda, New York

6 Results of radon measurements in indoor air at Building 31 , former Linde Uranium Refinery, Tonawanda, New York 



\section{ACKNOWLEDGMENTS}

The portion of this project completed after October 1, 1997, was sponsored by the U.S. Army Corps of Engineers, Buffalo District. Prior to that date, the project was sponsored by the Office of Environmental Restoration, U.S. Department of Energy, under contract DE-AC05-84OR21400 with Martin Marietta Energy Systems, Inc., and DE-AC05-960R22464 with Lockheed Martin Energy Research Corp.

The authors wish to acknowledge the contributions of G. H. Cofer, R. L. Coleman, R. C. Gosslee, D. D. McKinney, M. E. Murray, V. P. Patania, D. E. Rice, D. A. Roberts, R. E. Rodriguez, D. A. Rose, M. A. Rose, and W. Winton of the Measurement Applications and Development Group, Oak Ridge National Laboratory, for sample preparation and participation in the collection, analyses, editing, and reporting of data for this survey. The authors also wish to acknowledge the assistance of J. Wade of the Measurement Applications and Development Group, who conducted the radon sampling, and of Ron Brown and Tom Dugan, Praxair Safety Officers. 



\begin{abstract}
As part of the Formerly Utilized Sites Remedial Action Program, a team from Oak Ridge National Laboratory (ORNL) conducted a radiological verification survey of Building 31 at the former Linde Uranium Refinery, Tonawanda, New York. The purpose of the survey was to verify that remedial action completed by the project management contractor had reduced contamination levels to within authorized limits. Prior to remediation, fixed radioactive material was prevalent throughout the building and in some of the duct work. Decontamination consisted of removing surface contamination from floors, baseboards, and overhead areas; removing some air ducts; and vacuuming dust.

Building 31 at the former Linde site in Tonawanda, New York, was thoroughly investigated inside and outside for radionuclide residues. The verification team discovered previously undetected contamination beneath the concrete pad on the first floor and underneath floor tiles on the second floor. All suspect floor tiles were removed and any contamination beneath them cleaned to below guideline levels. The verification team also discovered elevated radiation levels associated with overhead air lines that led to the eventual removal of the entire air line and a complete investigation of the history of all process piping in the building.

Final verification surveys showed that residual surface beta-gamma activity levels were slightly elevated in some places but below U.S. Department of Energy applicable guidelines for protection against radiation (Table 1). Similarly, removable radioactive contamination was also below applicable guidelines. Exposure rates within the building were at typical background levels, and no consistently elevated indoor radon concentrations were measured. However, radionuclide analysis of subsurface soil from beneath the concrete floor on the ground level showed concentrations of ${ }^{238} \mathrm{U}$ and ${ }^{226} \mathrm{Ra}$ that exceeded applicable guidelines. At the time of this survey, there was no measured exposure pathway for this subslab contamination under current use scenarios, and there was low risk associated with this contamination if the concrete slab is not cracked or penetrated. However, any penetration of the concrete slab caused by renovations, repairs, demolition, or a naturally-occurring crack, would require further investigation and evaluation.
\end{abstract}

Analysis of the project management contractor's post-remedial action data and results of this independent radiological verification survey by ORNL confirm that all radiological measurements inside the building, on the exterior walls, and on the roof are below the limits prescribed by applicable guidelines for protection against radiation. 


\title{
Results of the Independent Radiological Verification Survey of the Remediation at Building 31, Former Linde Uranium Refinery, Tonawanda, New York (LI001V)*
}

\author{
INTRODUCTION
}

From 1942 through approximately 1948, the Linde Air Products Division of Union Carbide Corporation, Tonawanda, New York, was one of many companies performing work associated with the development of nuclear energy for defense-related projects. This work was conducted under government contract to the Manhattan Engineer District (MED) and the Atomic Energy Commission (AEC). During the first 3 years, pitchblende ore from the Belgian Congo and concentrates from the Colorado Plateau ore were converted to $\mathrm{U}_{3} \mathrm{O}_{8}$. A second process yielding $\mathrm{UO}_{2}$ was conducted for about a year, and a third process, converting $\mathrm{UO}_{2}$ to green salt $\left(\mathrm{UF}_{4}\right)$, operated during World War II and the following 2 years. Linde also developed and produced barrier material for the Oak Ridge Gaseous Diffusion Plant. Other contracts have been identified, but the exact nature of the work involved is unknown (DOE 1980).

As a result of these and similar activities, equipment, buildings, and land at some of the sites became radiologically contaminated resulting in low levels of contamination on the properties. At contract termination, sites used by contractors were decontaminated in accordance with the standards and survey methods in use at that time. Since the original assessments, radiological criteria and guidelines for the release of such sites for unrestricted use have become more stringent. In some instances, records documenting decontamination efforts cannot be found, and the final radiological conditions of the site cannot be adequately determined. As a result, the Formerly Utilized Sites Remedial Action Program (FUSRAP) was established in 1974 to identify these formerly used sites and to reevaluate their radiological status (DOE 1980). The radiological survey detailed in this report was performed under the FUSRAP program.

The Linde site was investigated in October and November 1976 to determine the extent of on-site radiological contamination (DOE 1978). At that time, the investigation included direct measurements of alpha contamination and beta-gamma dose rates on floors, walls, ceilings, supports, and roof; collection of smear samples in the same locations to assess transferable contamination; measurement of external gamma levels; radiological analysis of exterior soil samples; and measurement of instantaneous radon concentrations. Because contamination in some areas was above limits set by then current federal guidelines for release of property for unrestricted use, the property was designated for remediation under FUSRAP (DOE 1978).

A remedial investigation/feasibility study-environmental impact statement process was conducted to obtain sufficient site-specific information for assessment of the nature and extent of contamination at the Tonawanda site and evaluation of remedial action alternatives (DOE 1993). This process included performing a characterization and identifying areas requiring additional investigation. Only two points on roof vents in Building 31 showed radioactive contamination. According to the remedial investigation report, uranium dioxide was fluorinated to produce uranium tetrafluoride in Building 31. Since, the limited nature of contamination seemed inconsistent with the fluorination process used at that time and

The survey was performed by members of the Measurement Applications and Development Group of the Life Sciences Division at Oak Ridge National Laboratory. 
the amount of contamination found in similar buildings at the Linde site, Building 31 was scheduled for further investigation and remedial action.

In 1995, Bechtel National, Inc. (BNI), the project management contractor designated by DOE, began remediation activities at Building 31. After BNI completed remediation in an area of the building, an independent verification survey of the remediated area was conducted by the Measurement Applications and Development Group of ORNL at the request of DOE's Office of Environmental Restoration. An independent verification contractor is assigned to ensure the effectiveness of remedial activities performed within FUSRAP and to confirm compliance with applicable guidelines.

This report describes the independent radiological verification activities conducted intermittently by ORNL from October 1995 to June 1998 at Building 31 at the former Linde Uranium Refinery. The objectives of the verification activities were to confirm (1) that available documentation adequately and accurately described the post-remedial action status of the property that was to be verified, and (2) that remedial action reduced contamination levels to within authorized limits. Figure 1 shows the general location of the former Linde property in relation to other sites in Tonawanda. Figure 2 shows the location of Building 31 at the Linde site.

\section{SCOPE OF THE INVESTIGATION}

The radiological verification investigation included the following:

- Systematic measurements using field instruments for detection of low-energy radiation (FIDLER) at 2-m intervals on the first floor and at $0.5-\mathrm{m}$ intervals in selected areas of the second floor.*

- Collection and radiological analysis of soil samples from boreholes drilled through the concrete floor on the first floor of the building.

- Floor monitor surveys in areas where floor tiles had been removed, and beta-gamma scans of some other floor areas.

- Measurement of direct and transferable alpha and beta-gamma radiation levels at selected locations in the building.

- Thorough beta-gamma scans of the horizontal surfaces associated with interior overhead areas, including I-beams, cross ties, and wall/ceiling interfaces where contamination would most likely be concentrated.

- Thorough beta-gamma scans of the building interior baseboards (wall/floor interfaces), and verification of BNI wall survey data.

- Spot checks for contamination in additions and newly remodeled areas of the building.

- Measurement of indoor radon levels in several areas of the building.

- Radiological surveys of exterior walls, and examination of BNI roof survey data.

- Examination of post-remedial action data collected by BNI.

A radiological survey of exterior surface soil and grounds in the vicinity of Building 31 was not within the scope of this investigation. However, examination of the project management contractor's

*Floor grid size was selected based on suspected contamination, area, and time and cost considerations. The first floor covered a wide expanse and the survey crew was looking for large areas of soil contamination beneath the concrete, therefore, a 2-m grid was deemed sufficient. The second floor rooms were smaller and the survey crew was looking for small spots of contamination on the surface of the concrete beneath floor tiles in areas that had formerly been used as laboratories, therefore a 0.5 -m grid was selected. 
post-remedial action report is a required part of verification, and this activity will be completed as soon as the report becomes available.

\section{SURVEY METHODS}

A comprehensive description of the survey methods and instrumentation used in this survey is given in Procedures Manual for the ORNL Radiological Survey Activities (RASA) Program, ORNL/TM-8600 (Myrick et al. 1987) and Measurement Applications and Development Group Guidelines, ORNL-6782 (ORNL 1995).

Bicron miniscaler/ratemeters with Geiger-Mueller (GM) pancake detectors were used to measure beta-gamma radiation levels. Radiation levels in counts per minute (cpm) were converted to disintegrations per minute (dpm) per $100 \mathrm{~cm}^{2}$. Gamma radiation levels were determined using portable sodium iodide ( $\mathrm{NaI}$ ) gamma scintillation counters connected to Victoreen Model 490 Thyac III ratemeters. Because $\mathrm{NaI}$ gamma scintillators are energy dependent, measurements of gamma radiation levels in counts per minute were correlated to pressurized ionization chamber (PIC) measurements to determine gamma exposure rates in microroentgen per hour $(\mu \mathrm{R} / \mathrm{h})$. Alpha radiation levels were measured with Bicron scaler/ratemeters connected to zinc sulfide scintillation probes.

Electret radon monitors manufactured by Rad Elec Inc. were used to measure radon concentrations in indoor air. The electret ion chamber contains an electrically charged Teflon ${ }^{\mathrm{TM}}$ disk that attracts ions produced by the decay of radon and its decay products. The attracted ions cause a reduction in the electret's surface voltage. When the electret charge is measured before and after deployment, the change in total charge over the elapsed time period is proportional to the cumulative radon exposure. (Only the radon present in the room air, and not the radon progeny, can enter the electret chamber. The subsequent decay of the radon and the progeny resulting inside the chamber produces the measured ionization.)

FIDLER detection systems were used to measure the relative gamma fluence at the surface with the purpose of detecting gamma emitting radionuclide contamination beneath poured concrete floors on the first floor and beneath floor tiles on the second floor. The FIDLER is a NaI(TI) scintillation probe that is designed to be particularly sensitive to low-energy gamma and $\mathrm{x}$-ray radiation. The sensitive volume is $5 \mathrm{in}$. in diameter by $0.063 \mathrm{in}$. thick and is very efficient at measuring gamma fluence rates entering perpendicular to the entrance window. The FIDLER is also sensitive to beta radiation and can be highly efficient for detecting this depending on the configuration used.

FIDLER measurements were made at 2-m intervals on the first floor to ascertain that no large areas of soil contamination were present beneath the concrete slab. Similarly, FIDLER measurements were made at $0.5-\mathrm{m}$ intervals in selected rooms and the hallway of the second floor to make certain that no contaminated spots were present on the surface of the concrete beneath floor tiles in former laboratory areas. Measurements in counts per minute were taken with three different instruments and then normalized such that the observed values would appear to have come from only a single detector.

Sixteen subsurface (from depth of 15 to $45 \mathrm{~cm}$ ) soil samples were collected at 10 locations underneath the building by core drilling through concrete on the first floor. These biased samples* were collected at points representing a range (high to low) of subsurface radiation levels as indicated by

*Systematic subsurface soil sampling using preselected grid locations or random locations selected irrespective of FIDLER measurements was not conducted. 
surface FIDLER measurements. Concentrations of ${ }^{226} \mathrm{Ra},{ }^{232} \mathrm{Th}$, and ${ }^{238} \mathrm{U}$ were determined in soil samples using gamma spectrometry with hyper-pure germanium (HPGe) systems.

Floors in some areas of the building were surveyed with the Ludlum Model 239-1F gas flow proportional detector system ("floor monitor"), which includes a Ludlum Model 2221 scaler/ratemeter connected to a Ludlum Model 43-37 detector probe mounted on a roll-around cart. The monitor was set in the beta mode (high voltage setting) where it is primarily used to detect beta radiation, although it is also sensitive to alpha and gamma in this mode. Anomalies detected with the floor monitor were further characterized with the GM pancake detector. Questionable spots with elevated radiation levels were sometimes analyzed on-site using a portable $\mathrm{NaI}$ gamma spectroscopy system. Gamma spectra were observed and compared to spectra of the radionuclides of concern.

Smear samples were obtained by wiping selected surfaces inside the building in order to assess removable alpha and beta-gamma activity levels. Samples were counted using a gross alpha smear counter and a gross beta smear counter.

A scissor lift and a man lift were used to access high overhead areas inside the building; a man lift was used for the building exterior. Approximately $50 \%$ to $60 \%$ of the exterior wall area was surveyed between the ground and a height of 10 to $12 \mathrm{ft}$. Exterior wall surfaces more than $12 \mathrm{ft}$ off the ground were spot checked for contamination.

\section{VERIFICATION SURVEY RESULTS}

Applicable guidelines for protection against radiation are summarized in Table 1. Typical background radiation levels for the Tonawanda, New York, area are presented in Table 2. These data are provided for comparison with survey results presented in this section. Gamma radiation levels are presented in gross microroentgens per hour and FIDLER measurements in gross counts per minute. Similarly, background concentrations have not been subtracted from radionuclide concentrations in soil. Background count rates are subtracted in the conversion of alpha and beta-gamma count rates to disintegrations per minute per $100 \mathrm{~cm}^{2}\left(\mathrm{dpm} / 100 \mathrm{~cm}^{2}\right)$.

\section{GAMMA AND ALPHA RADIATION LEVELS}

Gamma exposure rates in Building 31 generally ranged from 8 to $13 \mu \mathrm{R} / \mathrm{h}$, which is similar to typical background levels in the Tonawanda, New York, area (Table 2). Higher levels could be attributed to naturally occurring radioactive materials in brick and concrete. Direct alpha measurements were taken at numerous random locations throughout the building during all stages of remediation and verification. Final direct alpha measurements in all verified areas were well below applicable guideline values (Table 1).

\section{FIDLER MEASUREMENTS}

Results of FIDLER measurements on the surface of the first floor are shown on Fig. 3. Normalized measurements ranged from 3500 to $17,000 \mathrm{cpm}$. Discounting slightly increased readings due to the geometry of a comer/wall measurement, most of the higher measurements were concentrated in the east, and particularly the northeast, part of the building. This grouping of elevated FIDLER measurements suggested that subsurface contamination might be present beneath the concrete floor. Elevated FIDLER measurements were used to select locations for the collection of subsurface soil samples, which confirmed the presence of contamination. FIDLER measurements also confirmed that excessive beta-gamma emitting contaminants were not present on the surface. 
Results of FIDLER measurements on the second floor are shown on Fig. 4. Normalized measurements ranged from 2700 to $13,000 \mathrm{cpm}$. Elevated FIDLER measurements on the tile and mastic material in rooms 214,215 , and 216 prompted further investigation. These rooms were used as labs during the time of the MED contract. Removal of tiles and analysis with a portable NaI gamma spectroscopy system indicated strong ${ }^{226} \mathrm{Ra}$ peaks in Room 215 and ${ }^{238} \mathrm{U}$ peaks in Room 216 . This method identified contamination in excess of cleanup guidelines beneath the tiles. The tiles were removed and the contaminated areas remediated (see section on Beta-Gamma Activity Levels) by the BNI radiological support subcontractor. (The ${ }^{226} \mathrm{Ra}$ in Room 215 was later determined to be a component in the concrete.)

\section{SOIL SAMPLES}

Biased soil sample locations are shown in Fig. 5, and results of radiological analyses are listed in Table 3. Surface samples ( 0 to $15 \mathrm{~cm}$ ) consisted of the concrete plugs, which were returned to the core holes. Concentrations of ${ }^{238} \mathrm{U}$ in subsurface soil $(15-46 \mathrm{~cm})$ ranged from 0.52 to $5.6 \mathrm{pCi} / \mathrm{g}$ at seven sample locations and from 40 to $230 \mathrm{pCi} / \mathrm{g}$ at the remaining three locations. Concentrations of ${ }^{226} \mathrm{Ra}$ in subsurface soil ranged from 0.53 to $6.2 \mathrm{pCi} / \mathrm{g}$ at seven sample locations and from 21 to $250 \mathrm{pCi} / \mathrm{g}$ at the remaining three locations. The same three sampling locations (VB15, VB19, and VB20) exceeded applicable guideline values for both ${ }^{238} \mathrm{U}$ and ${ }^{226} \mathrm{Ra}$. All three sampling locations were located beneath Room 114. Typical background levels for ${ }^{238} \mathrm{U}$ and ${ }^{226} \mathrm{Ra}$ in the Tonawanda area (Table 2) were exceeded at sampling locations VB13, VB16, VB17, and VB18, which were located beneath rooms 110 , 111 , and 112. Concentrations of ${ }^{232} \mathrm{Th}$ in subsurface soil ranged from 0.22 to $3.0 \mathrm{pCi} / \mathrm{g}$ with one sample above typical background levels for ${ }^{232} \mathrm{Th}$ (Table 2), but all samples were well below applicable guideline values (Table 1) for this radionuclide.

\section{SMEAR SAMPLE ANALYSIS}

First floor smear sample locations are shown in Fig. 6, and second floor locations are shown in Fig. 7. Results of smear sample analysis are given in Table 4. No removable alpha or beta-gamma emitting material was measured in smear samples collected on the first floor. Before final remediation, second floor smear samples showed small amounts of removable alpha emitting material in samples VTI and VT2 (Room 203), VT3 (Room 207), and VT19 (second floor hallway), and a small amount of removable beta-gamma emitting material in sample VT1 (Room 203). These areas were not verified below guidelines on the dates these smears were taken (See Table 5). More remediation was recommended and conducted in these rooms. The small amounts of removable radioactivity in smears VT5 (Room 205), VT12 (Room 215), and VT18 (Room 202) were well below guideline values. Based on these and other survey results, these rooms were verified below guidelines on the dates the smears were taken. After all remediation and verification activities were completed at Building 31 , all removable radioactivity levels were well below applicable guidelines (Table 1).

\section{BETA-GAMMA ACTIVITY LEVELS}

Results of the surface beta-gamma scans of the floors, baseboards, walls, and overhead areas on both the first and the second floor are summarized in Table 5. Detailed survey drawings are on file. The term "verified below guidelines" is used in Table 5 to indicate that scan results showed total residual surface beta-gamma contamination below the applicable guideline limits listed in Table 1 for uranium (maximum 15,000 dpm/100 cm 2 , average $5000 \mathrm{dpm} / 100 \mathrm{~cm}^{2}$, and removable $1000 \mathrm{dpm} / 100 \mathrm{~cm}^{2}$ ). Therefore, an area with scan results ranging from 3400 to $6400 \mathrm{dpm} / 100 \mathrm{~cm}^{2}$, is below guidelines if the average measurement is $\leq 5000 \mathrm{dpm} / 100 \mathrm{~cm}^{2}$ in any one square meter. Areas exceeding applicable guideline limits are classified as "needs further remediation" or "needs further investigation." 
As indicated by Table 5, many areas of the building were scanned more than one time and on more than one date. When verification surveys indicated that applicable guideline values (Table 1) had not been achieved, additional remediation was required. Following the verification team's recommendation, tiles covering the floor in several rooms on the second floor were removed and subsurface areas remediated to ensure that no contamination remained below the tiles. The verification team's discovery of elevated radiation levels associated with air lines in rooms 105 and 102 led to the eventual removal of the entire air line and a complete investigation of the history of all process piping in Building 31. Some areas of Building 31 still have easily detectable radioactive materials remaining, but none of these areas exceed applicable guideline values for total residual surface contamination (Table 1).

A survey of Building 31 exterior walls revealed an area associated with a transformer that was above guidelines (Table 1). This area was remediated and resurveyed by the BNI radiological support subcontractor. With the exception of the transformer area, no elevated radioactivity levels were found during the survey of Building 31 exterior walls or during verification of roof survey data collected by BNI.

\section{INDOOR RADON LEVELS}

Six electret radon monitors were deployed for 7 days at four locations from March 17 to 24,1998 , and an additional four monitors were deployed for 31 'days at four different locations from May 28 to June 29, 1998. The first four sampling locations are shown in Fig. 8. Sampling locations were selected to coincide with the highest subsurface soil radionuclide levels (Table 3 and Fig. 5) and the highest FIDLER measurements (Fig. 3). Results from all radon measurements are given in Table 6. One of the 7-day electrets showed radon concentrations of $5.2 \mathrm{pCi} / \mathrm{L}$ in Room 111 . This is slightly above the EPA action level of $4 \mathrm{pCi} / \mathrm{L}$. Two 31-day follow-up measurements in Room 111 showed concentrations of 0.5 and $0.8 \mathrm{pCi} / \mathrm{L}$, which falls within the range of the other seven radon measurements $(0.3$ to $1.7 \mathrm{pCi} / \mathrm{L})$ and well below the EPA action level.

\section{SIGNIFICANCE OF FINDINGS}

Prior to remediation, fixed alpha and beta-gamma emitting material was prevalent throughout Building 31 and in some of the duct work. Decontamination, performed by BNI and subcontractors under the direction of BNI, consisted of removal of surface contamination from floors, baseboards, and overhead areas; removal of some air ducts; and vacuuming of dust. This independent radiological verification survey was performed to verify that the remedial action had reduced contamination levels to within authorized limits.

Building 31 at the former Linde site in Tonawanda, New York, was thoroughly investigated inside and outside for radionuclide residues. Total residual surface activity levels were slightly elevated in some places but well below applicable guidelines for protection against radiation. Similarly, removable alpha and beta-gamma activity levels were also well below applicable guidelines. Exposure rates within the building were at typical background levels, and no consistently elevated indoor radon concentrations were measured. However, radionuclide analysis of subsurface soil from beneath the concrete floor on the ground level showed concentrations of ${ }^{238} \mathrm{U}$ and ${ }^{226} \mathrm{Ra}$ that exceeded applicable guidelines. At the time of this survey, there was no exposure pathway for this subslab contamination under current use scenarios, and there was low risk associated with this contamination if the concrete slab is not cracked or penetrated. However, any penetration of the concrete slab caused by renovations, repairs, demolition, or a naturally-occurring crack, would require further investigation and evaluation. 
Analysis of the project management contractor's post-remedial action data and results of this independent radiological verification survey by ORNL confirm that all radiological measurements inside the building, on the exterior walls, and on the roof are below the limits prescribed by U.S. Department of Energy applicable guidelines for protection against radiation.

\section{REFERENCES}

DOE (U.S. Department of Energy). May 1978. Radiological Survey of the Former Linde Uranium Refinery, Tonawanda, New York, DOE/EV-0005/5, UC-70, U.S. Department of Energy, Division of Environmental Control Technology, Formerly Utilized MED/AEC Sites Remedial Action Program.

DOE (U.S. Department of Energy). September 1980. A Background Report for the Formerly Utilized Manhattan Engineer District/Atomic Energy Commission Sites Program, DOE/EV-0097.

DOE (U.S. Department of Energy). February 1993. Remedial Investigation Report for the Tonawanda Site, Tonawanda, New York, DOE/OR/21949-300, U.S. Department of Energy, Formerly Utilized Sites Remedial Action Program.

Myrick, T. E., et al. April 1987. Procedures Manual for the ORNL Radiological Survey Activities (RASA) Program, ORNL/TM-8600, Martin Marietta Energy Systems, Inc., Oak Ridge Natl. Lab.

ORNL (Oak Ridge National Laboratory). January 1995. Measurement Applications and Development Group Guidelines, ORNL-6782, Martin Marietta Energy Systems, Inc., Oak Ridge Natl. Lab. 


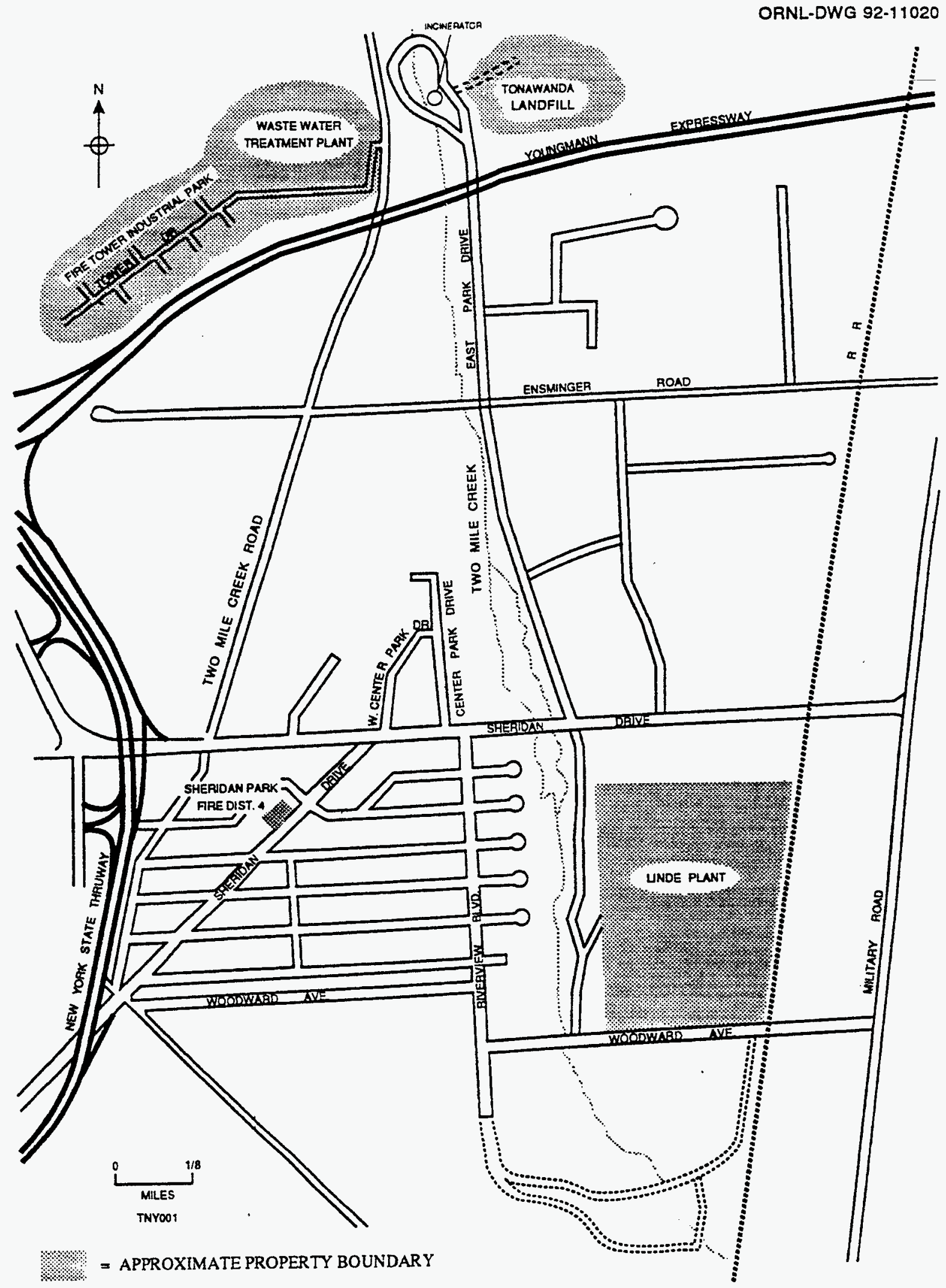

Fig. 1. Diagram showing general location of the former Linde site in Tonawanda, New York. 


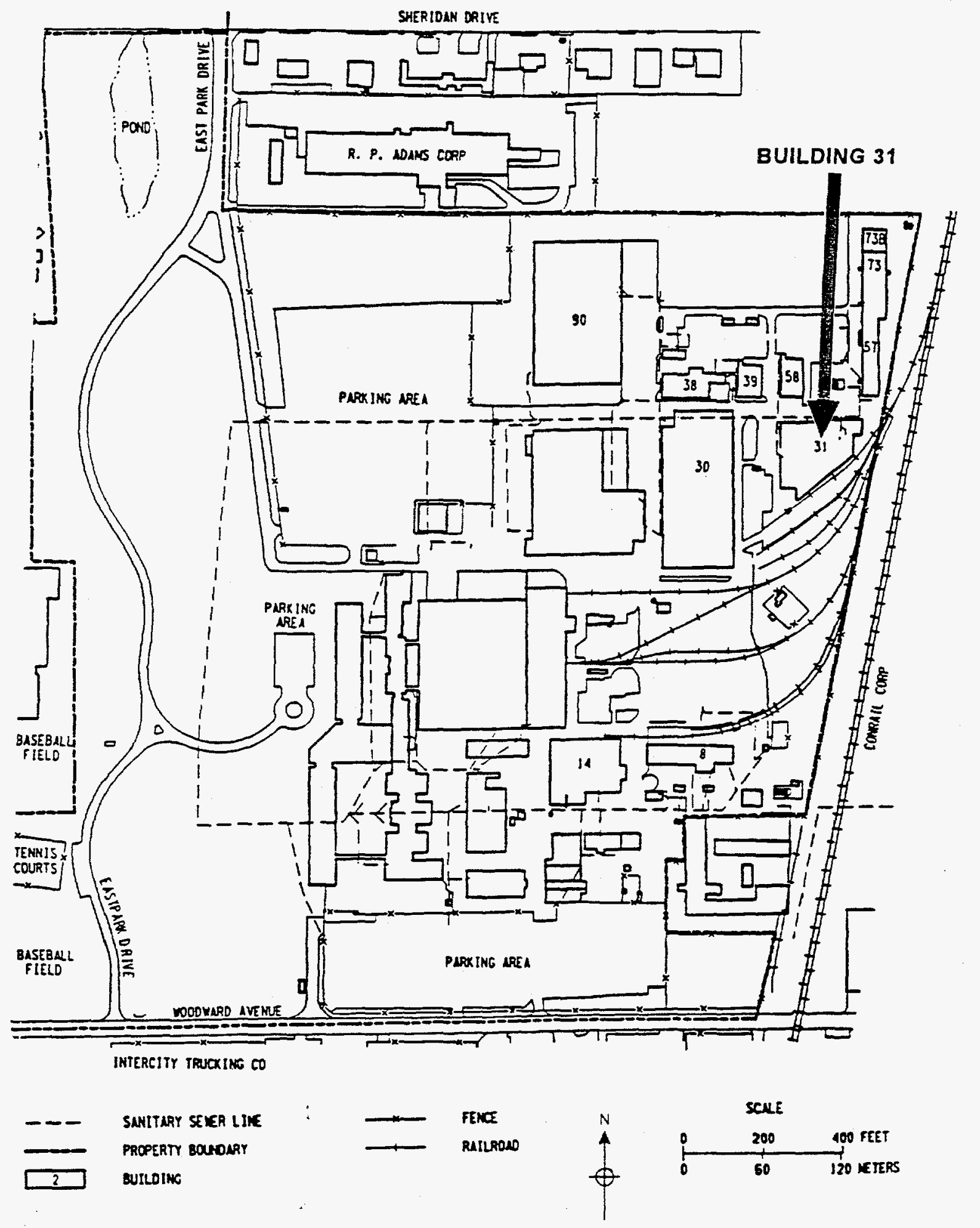

Fig. 2. Diagram showing general location of Building 31, at the former Linde site, Tonawanda, New York. 


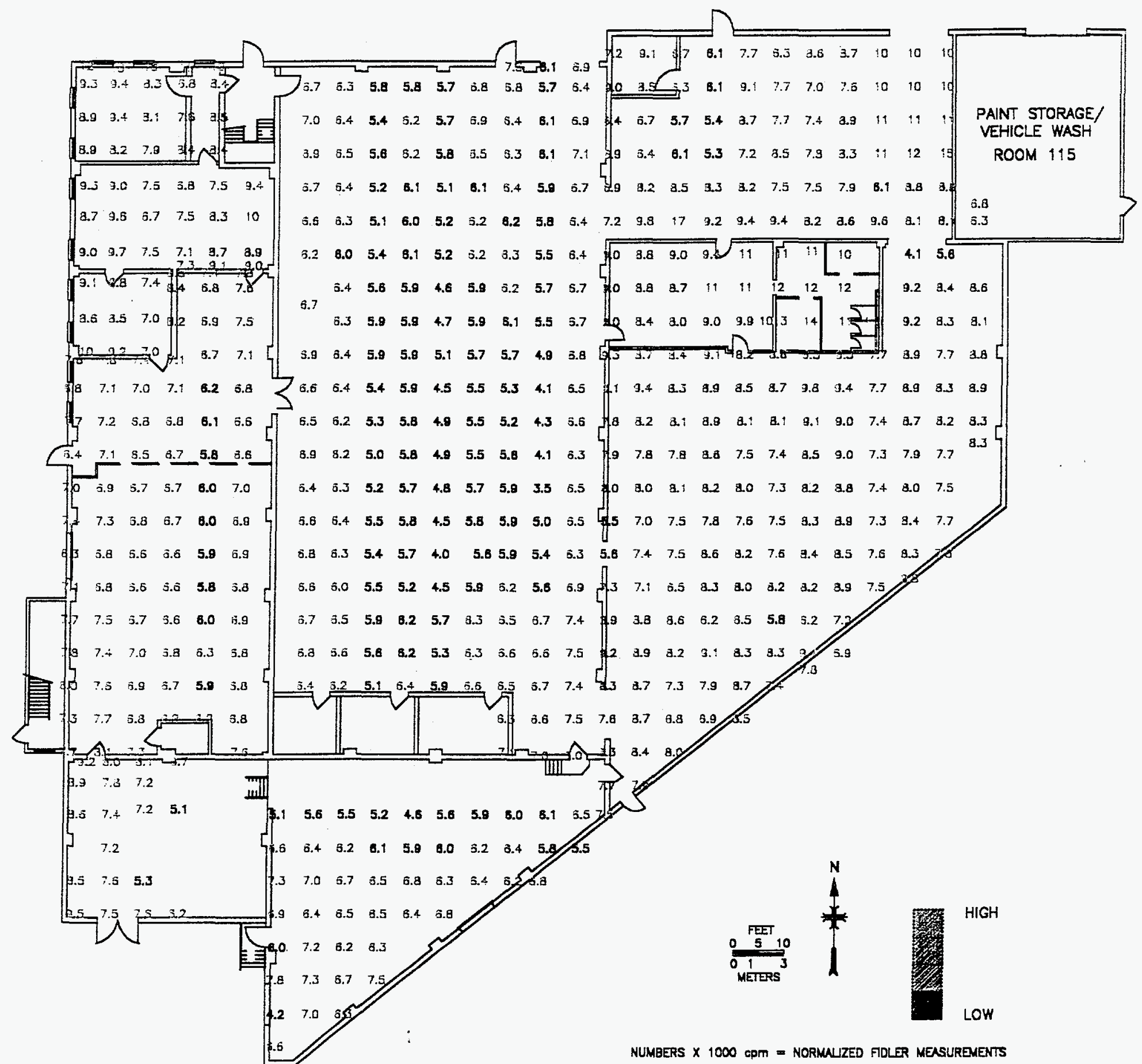

Fig. 3. Diagram showing first floor FIDLER measurements at Building 31. 


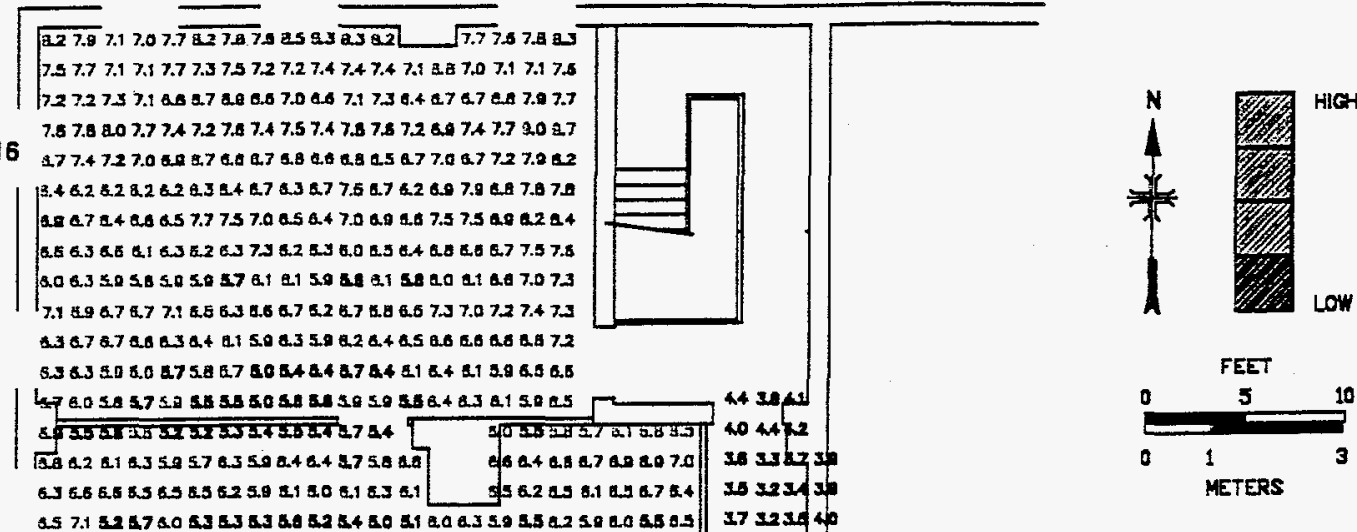

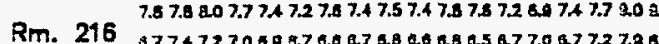

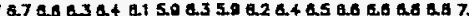
$404+2$ 30.23

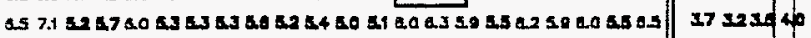

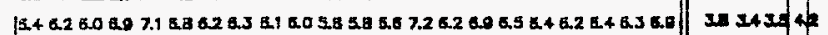

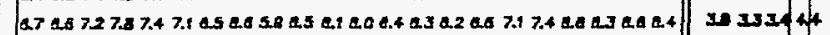

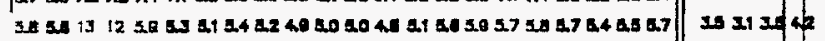

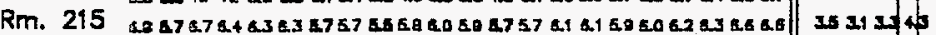

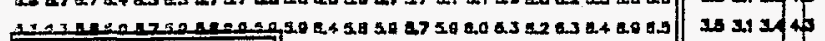

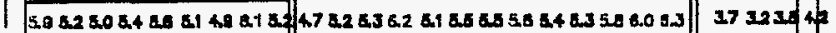
Rm. 214

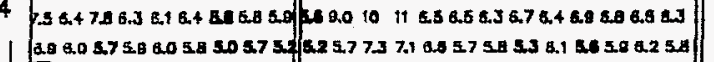
$50325 \times 43$ 383214 th 10323.

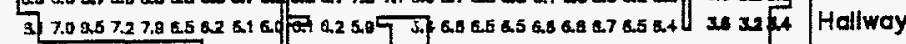

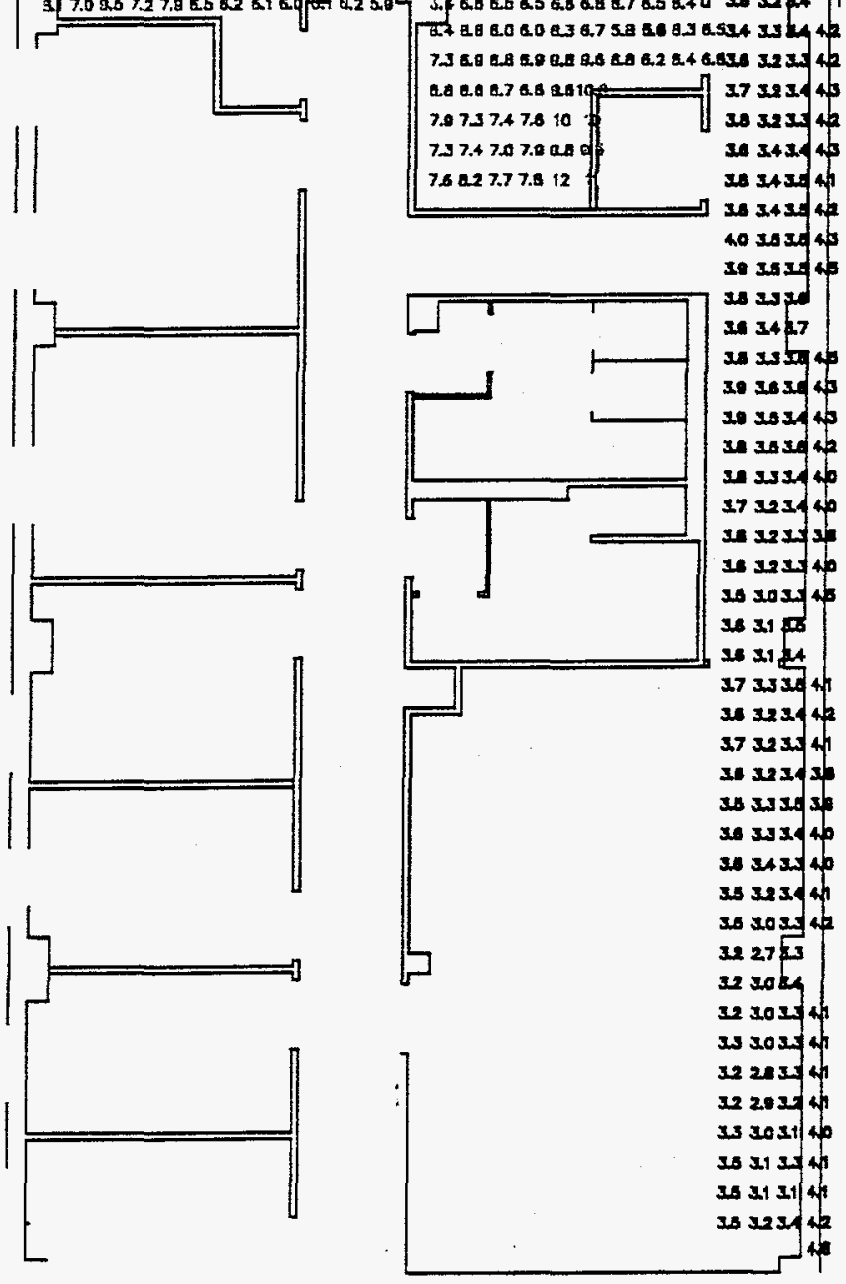

NUMEERS $\times 1000 \mathrm{cpm}$ NORMALZED FOLER MEASUREMDIT

Fig. 4. Diagram showing second floor FIDLER measurements at Building 31 . 


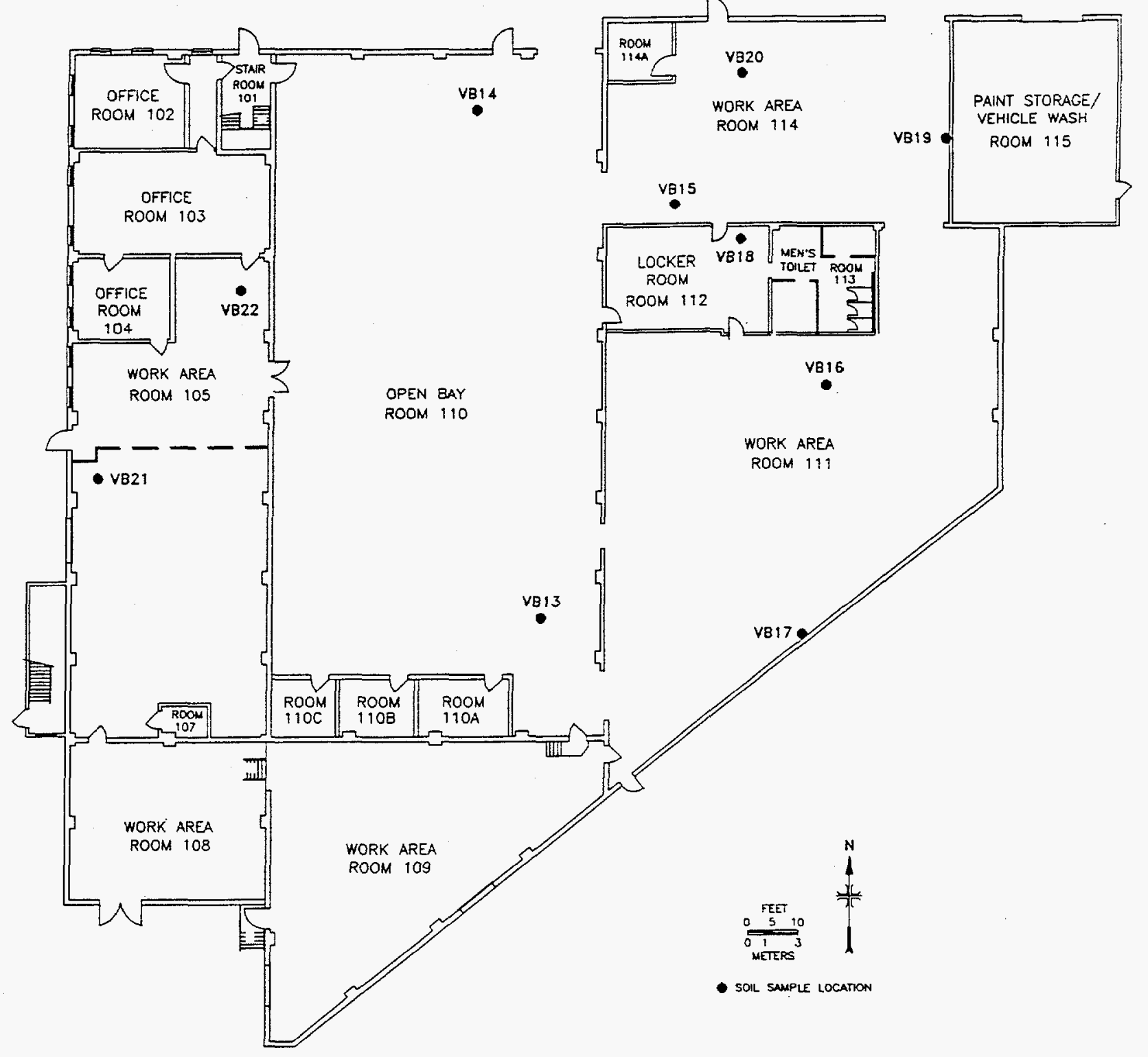

Fig. 5. Diagram showing location of biased soil samples collected underneath the first floor at Building 31 . 


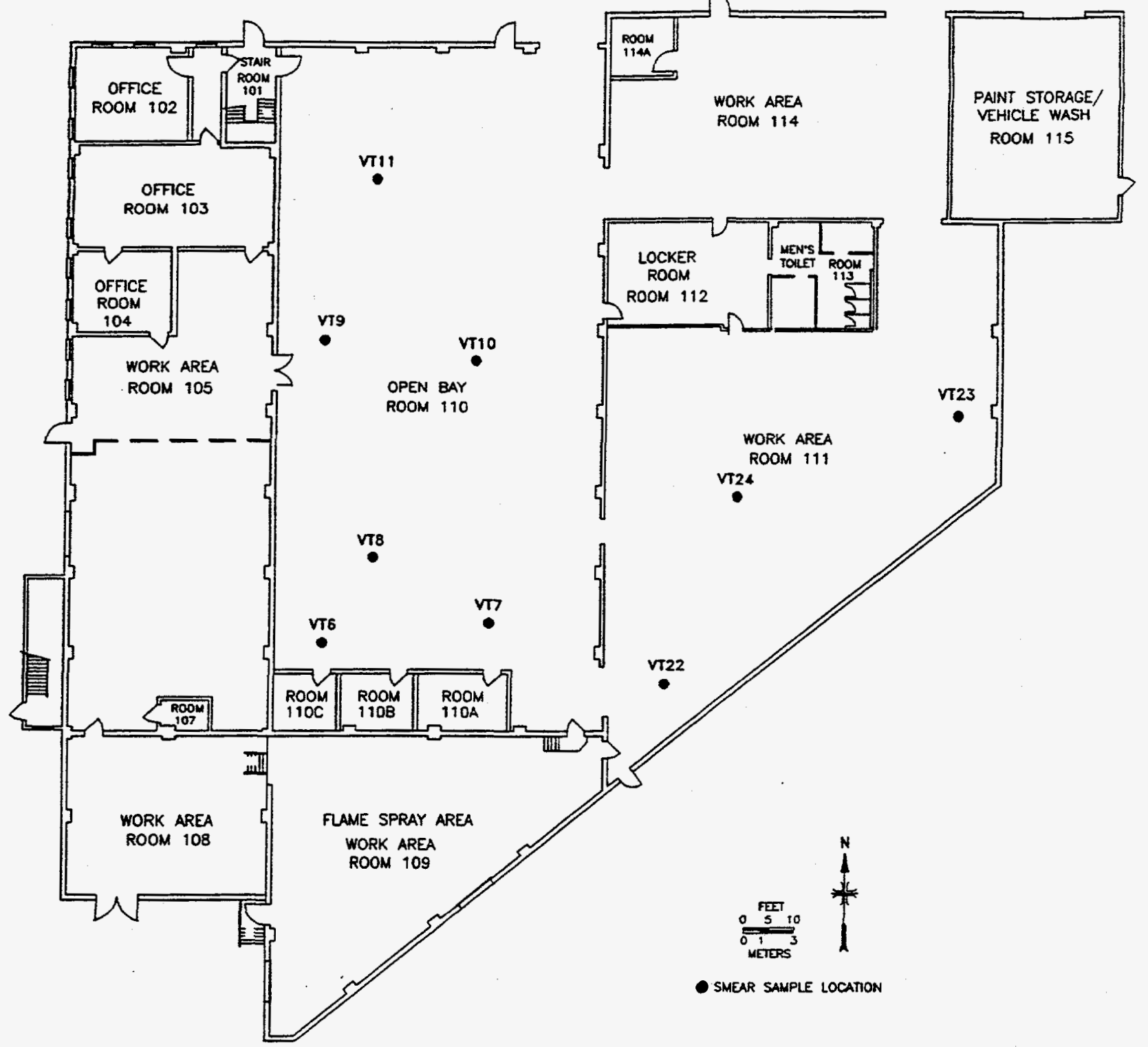

Fig. 6. Diagram showing first floor smear sample locations at Building 31 . 


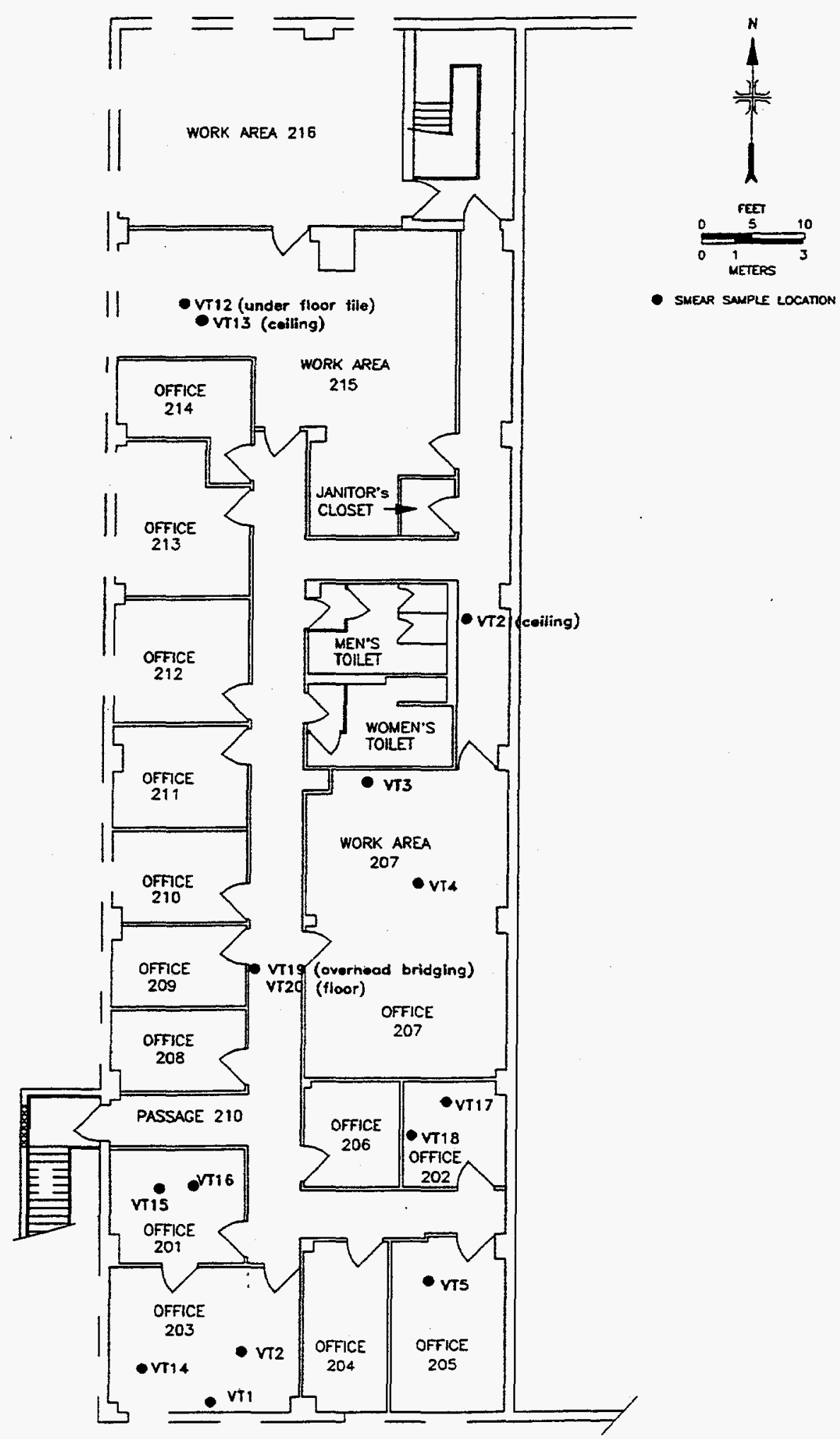

Fig. 7. Diagram showing second floor smear sample locations at Building 31. 


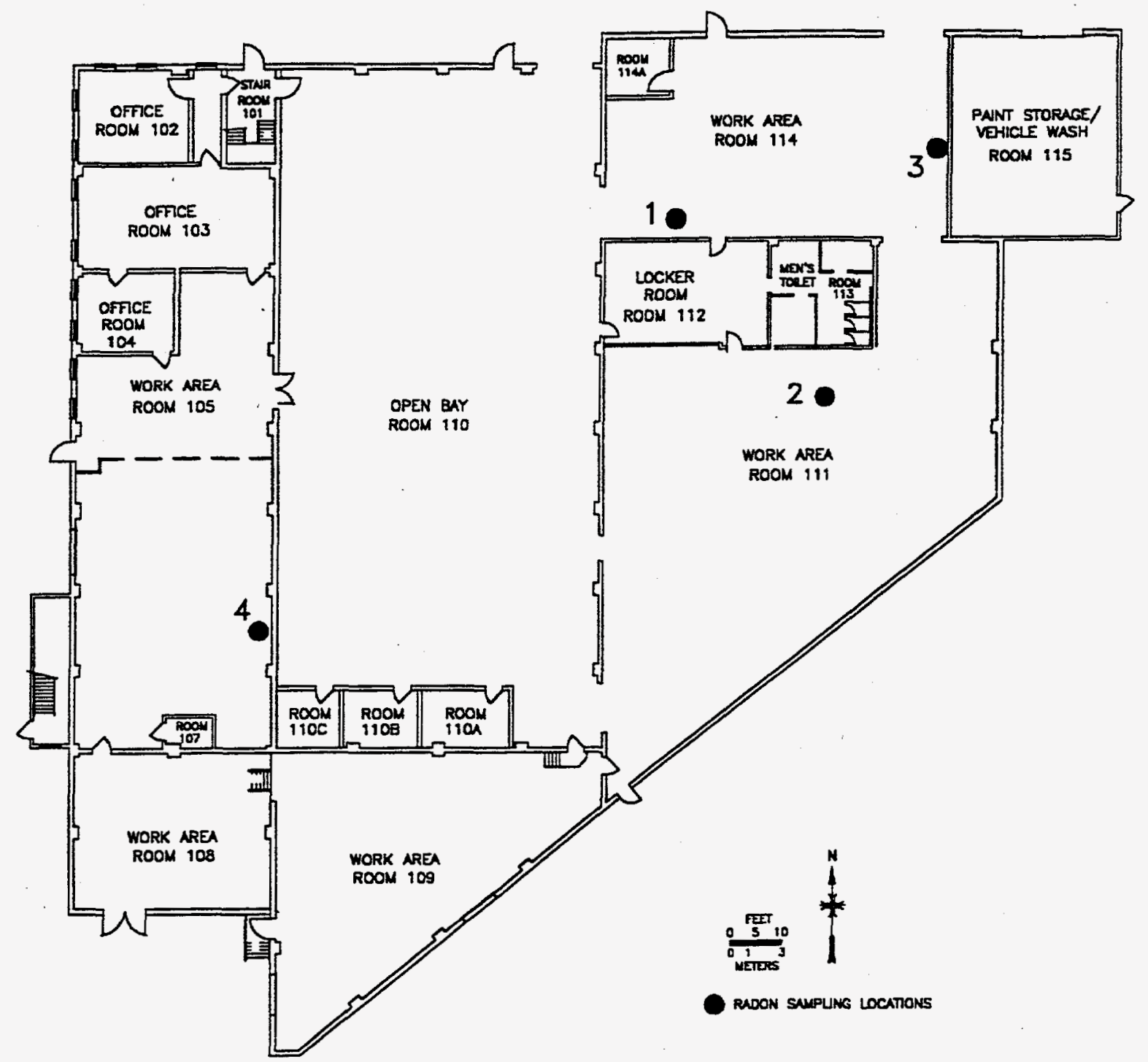

Fig. 8. Diagram showing 7-day radon sampling locations at Building 31. 
Table 1. Applicable guidelines for protection against radiation

(Limits for uncontrolled areas)

\begin{tabular}{|c|c|c|}
\hline Mode of exposure & Exposure conditions & Guideline value \\
\hline \multicolumn{3}{|c|}{ Indoor gamma } \\
\hline Gamma radiation & $\begin{array}{l}\text { Indoor gamma radiation level } \\
\text { (above background) }\end{array}$ & $20 \mu \mathrm{R} / \mathrm{h}^{a}$ \\
\hline \multicolumn{3}{|c|}{ Surface contamination } \\
\hline \multirow[t]{5}{*}{$\begin{array}{l}\text { Total residual surface } \\
\text { contamination in } \\
\text { any one square } \\
\text { meter }^{b}\end{array}$} & $\begin{array}{l}{ }^{238} \mathrm{U},{ }^{235} \mathrm{U}, \mathrm{U} \text {-natural (alpha } \\
\text { emitters) or } \\
\text { Beta-gamma emitters } \\
\text { Maximum } \\
\text { Average } \\
\text { Removable }\end{array}$ & $\begin{array}{l}15,000 \mathrm{dpm} / 100 \mathrm{~cm}^{2} \\
5,000 \mathrm{dpm} / 100 \mathrm{~cm}^{2} \\
1,000 \mathrm{dpm} / 100 \mathrm{~cm}^{2}\end{array}$ \\
\hline & $\begin{array}{l}{ }^{232} \mathrm{Th} \text {, Th-natural (alpha } \\
\text { emitters) }\end{array}$ & \\
\hline & $\begin{array}{l}{ }^{90} \mathrm{Sr} \text { (beta-gamma emitter) } \\
\text { Maximum } \\
\text { Average } \\
\text { Removable }\end{array}$ & $\begin{array}{l}3,000 \mathrm{dpm} / 100 \mathrm{~cm}^{2} \\
1,000 \mathrm{dpm} / 100 \mathrm{~cm}^{2} \\
200 \mathrm{dpm} / 100 \mathrm{~cm}^{2}\end{array}$ \\
\hline & $\begin{array}{l}{ }^{226} \mathrm{Ra},{ }^{230} \mathrm{Th} \text {, transuranics } \\
\text { Maximum } \\
\text { Average } \\
\text { Removable }\end{array}$ & $\begin{array}{l}300 \mathrm{dpm} / 100 \mathrm{~cm}^{2} \\
100 \mathrm{dpm} / 100 \mathrm{~cm}^{2} \\
20 \mathrm{dpm} / 100 \mathrm{~cm}^{2}\end{array}$ \\
\hline & \multicolumn{2}{|l|}{ Radionuclides in soil } \\
\hline $\begin{array}{l}\text { Radionuclide con- } \\
\text { centrations in soil } \\
\text { (generic) }\end{array}$ & $\begin{array}{l}\text { Maximum permissible con- } \\
\text { centration of the following } \\
\text { radionuclides in soil above } \\
\text { background levels, averaged } \\
\text { over a } 100-\mathrm{m}^{2} \text { area } \\
{ }^{226} \mathrm{Ra} \\
{ }^{232} \mathrm{Th} \\
{ }^{230} \mathrm{Th}\end{array}$ & $\begin{array}{l}5 \mathrm{pCi} / \mathrm{g} \text { averaged over the } \\
\text { first } 15 \mathrm{~cm} \text { of soil below the } \\
\text { surface; } 15 \mathrm{pCi} / \mathrm{g} \text { when } \\
\text { averaged over } 15-\mathrm{cm} \text {-thick } \\
\text { soil layers more than } 15 \mathrm{~cm} \\
\text { below the surface }\end{array}$ \\
\hline Derived concentrations & Total uranium & $60 \mathrm{pCi} / \mathrm{g}^{d}$ \\
\hline
\end{tabular}


Table 1 (continued)

\begin{tabular}{lll}
\hline Mode of exposure & Exposure conditions & Guideline value \\
\hline \multicolumn{1}{c}{$\begin{array}{c}\text { Soil hot spot criteria } \\
\text { Guideline for non- }\end{array}$} & $\begin{array}{l}\text { Applicable to locations with } \\
\text { homogeneous con- } \\
\text { tamination (used in } \\
\text { addition to the } 100-\mathrm{m}^{2}\end{array}$ & $\begin{array}{l}\mathrm{G}_{A}=\mathrm{G}(100 / \mathrm{A})^{1 / 2}, \\
\text { where }\end{array}$ \\
$\begin{array}{l}\text { cantly elevated concentrations } \\
\text { of radionuclides ("hot spots") }\end{array}$ & $\begin{array}{l}\mathrm{G}_{A}=\text { guideline for "hot } \\
\text { spot" of area (A) } \\
\end{array}$ & $\begin{array}{l}\mathrm{G}_{i}=\text { guideline averaged } \\
\text { over a } 100-\mathrm{m}^{2} \text { area }\end{array}$ \\
\hline
\end{tabular}

The $20 \mu \mathrm{R} / \mathrm{h}$ shall comply with the basic dose limit (100 mrem/year) when an appropriate-use scenario is considered.

${ }^{b}$ These surface contamination guidelines are consistent with NRC Guidelines for Decontamination at Facilities and Equipment Prior to Release for Unrestricted Use or Termination of Licenses for By-Product, Source, or Special Nuclear Material, May 1987.

Beta-gamma emitters (radionuclides with decay modes other than alpha emission or spontaneous fission) except ${ }^{90} \mathrm{Sr},{ }^{228} \mathrm{Ra},{ }^{223} \mathrm{Ra},{ }^{227} \mathrm{Ac},{ }^{133} \mathrm{I},{ }^{129} \mathrm{I},{ }^{126} \mathrm{I},{ }^{125} \mathrm{I}$.

${ }^{d}$ Guidelines for uranium are derived on a site-specific basis. A total uranium guideline of $60 \mathrm{pCi} / \mathrm{g}$ will be applied at the former Linde site. This corresponds to a ${ }^{238} \mathrm{U}$ concentration of $\sim 30 \mathrm{pCi} / \mathrm{g}$.

'Guidelines specify that every reasonable effort shall be made to identify and to remove any source that has a concentration exceding 30 times the guideline value, irrespective of area (adapted from Revised Guidelines for Residual Radioactive Material at FUSRAP and Remote SFMP Sites, April 1987).

Sources: Adapted from U.S. Department of Energy, DOE Order 5400.5, April 1990; U.S. Department of Energy, Guidelines for Residual Radioactive Material at Formerly Utilized Sites Remedial Action Program and Remote Surplus Facilities Management Program Sites, Rev. 2, March 1987; and U.S. Department of Energy, Radiological Control Manual, DOE/EH-0256T, April 1994. 
Table 2. Background radiation levels and concentrations of selected radionuclides in soil near Tonawanda, New York

\begin{tabular}{lcc}
\hline \multirow{2}{*}{$\begin{array}{c}\text { Type of radiation measurement } \\
\text { or sample }\end{array}$} & \multicolumn{2}{c}{$\begin{array}{c}\text { Radiation level or radionuclide } \\
\text { concentration }\end{array}$} \\
\cline { 2 - 3 } & Range & Average \\
\hline Gamma exposure rate at & $8-11$ & 9 \\
ground surface $(\mu \mathrm{R} /)^{a}$ & & \\
Concentration of radionuclides & & \\
in soil (pCi/g) & & 1.0 \\
${ }^{23} \mathrm{U}$ & $0.8-1.1$ & 0.9 \\
${ }^{226} \mathrm{Ra}$ & $0.7-1.1$ & 0.8 \\
${ }^{232} \mathrm{Th}$ & $0.5-0.9$ & \\
\hline
\end{tabular}

"Values obtained from four locations in the Tonawanda area.

Source: R. E. Rodriguez, M. E. Murray, and M. S. Uziel. October 1992. Results of the Radiological Sumvey at the Town of Tonawanda Landfill, Tonowanda, New York (TNY001), ORNL/RASA-92/12, Martin Marietta Energy Systems, Inc., Oak Ridge Natl. Lab. 
Table 3. Concentrations of radionuclides in soil samples, Building 31, former Linde Uranium Refinery, Tonawanda, New York

\begin{tabular}{|c|c|c|c|c|c|}
\hline \multirow{2}{*}{$\begin{array}{l}\text { Sample } \\
\mathrm{ID}^{a}\end{array}$} & \multirow{2}{*}{$\begin{array}{l}\text { Grid } \\
\text { Location }\end{array}$} & \multirow{2}{*}{$\begin{array}{l}\text { Depth }^{b} \\
\text { (cm) }\end{array}$} & \multicolumn{3}{|c|}{ Radionuclide concentration $(\mathrm{pCi} / \mathrm{g})^{c}$} \\
\hline & & & ${ }^{238} \mathrm{U}$ & ${ }^{226} \mathrm{Ra}$ & ${ }^{232} \mathrm{Th}$ \\
\hline \multicolumn{6}{|c|}{ Biased soil samples ${ }^{d}$} \\
\hline $\begin{array}{l}\text { VB13B } \\
\text { VB13C }\end{array}$ & $\begin{array}{l}17 \mathrm{~N}, 28 \mathrm{E} \\
17 \mathrm{~N}, 28 \mathrm{E}\end{array}$ & $\begin{array}{l}15-30 \\
30-38\end{array}$ & $\begin{array}{l}1.7 \pm 0.4 \\
1.2 \pm 0.4\end{array}$ & $\begin{array}{l}1.8 \pm 0.2 \\
1.2 \pm 0.2\end{array}$ & $\begin{array}{l}0.94 \pm 0.1 \\
0.73 \pm 0.1\end{array}$ \\
\hline $\begin{array}{l}\text { VB14B } \\
\text { VB14C }\end{array}$ & $\begin{array}{l}48 \mathrm{~N}, 24 \mathrm{E} \\
48 \mathrm{~N}, 24 \mathrm{E}\end{array}$ & $\begin{array}{l}19-30 \\
30-46\end{array}$ & $\begin{array}{r}0.95 \pm 0.3 \\
1.4 \pm 0.3\end{array}$ & $\begin{array}{l}1.0 \pm 0.1 \\
1.3 \pm 0.2\end{array}$ & $\begin{array}{l}0.41 \pm 0.09 \\
0.50 \pm 0.1\end{array}$ \\
\hline VB15B & $42 \mathrm{~N}, 36 \mathrm{E}$ & $20-33$ & $41 \pm 5$ & $89 \pm 1$ & $1.3 \pm 0.2$ \\
\hline $\begin{array}{l}\text { VB16B } \\
\text { VB16C }\end{array}$ & $\begin{array}{l}31 \mathrm{~N}, 45 \mathrm{E} \\
31 \mathrm{~N}, 45 \mathrm{E}\end{array}$ & $\begin{array}{l}13-28 \\
28-43\end{array}$ & $\begin{array}{l}3.8 \pm 0.4 \\
4.1 \pm 0.4\end{array}$ & $\begin{array}{l}5.2 \pm 0.3 \\
6.2 \pm 0.4\end{array}$ & $\begin{array}{l}1.1 \pm 0.1 \\
1.3 \pm 0.2\end{array}$ \\
\hline $\begin{array}{l}\text { VB17B } \\
\text { VB17C }\end{array}$ & $\begin{array}{l}16 \mathrm{~N}, 44 \mathrm{E} \\
16 \mathrm{~N}, 44 \mathrm{E}\end{array}$ & $\begin{array}{l}15-30 \\
30-46\end{array}$ & $\begin{array}{l}5.6 \pm 0.7 \\
4.9 \pm 0.5\end{array}$ & $\begin{array}{l}6.0 \pm 0.4 \\
5.7 \pm 0.4\end{array}$ & $\begin{array}{r}0.97 \pm 0.1 \\
1.3 \pm 0.2\end{array}$ \\
\hline $\begin{array}{l}\text { VB18B } \\
\text { VB18C }\end{array}$ & $\begin{array}{l}40 \mathrm{~N}, 40 \mathrm{E} \\
40 \mathrm{~N}, 40 \mathrm{E}\end{array}$ & $\begin{array}{l}15-30 \\
30-46\end{array}$ & $\begin{array}{l}5.3 \pm 0.7 \\
5.0 \pm 0.6\end{array}$ & $\begin{array}{l}6.0 \pm 0.3 \\
6.2 \pm 0.5\end{array}$ & $\begin{array}{c}0.79 \pm 0.08 \\
1.0 \pm 0.2\end{array}$ \\
\hline VB19B & $46 \mathrm{~N}, 52 \mathrm{E}$ & $30-46$ & $230 \pm 50$ & $250 \pm 20$ & $3.0 \pm 0.6$ \\
\hline $\begin{array}{l}\text { VB20B } \\
\text { VB20C }\end{array}$ & $\begin{array}{l}50 \mathrm{~N}, 40 \mathrm{E} \\
50 \mathrm{~N}, 40 \mathrm{E}\end{array}$ & $\begin{array}{l}15-30 \\
30-43\end{array}$ & $\begin{array}{l}40 \pm 5 \\
40 \pm 5\end{array}$ & $\begin{array}{l}22 \pm 1 \\
21 \pm 1\end{array}$ & $\begin{array}{r}0.41 \pm 0.2 \\
1.1 \pm 0.2\end{array}$ \\
\hline VB21B & $25.5 \mathrm{~N}, 1.5 \mathrm{E}$ & $15-30$ & $1.2 \pm 0.4$ & $0.98 \pm 0.1$ & $0.22 \pm 0.06$ \\
\hline VB22B & $37 \mathrm{~N}, 10 \mathrm{E}$ & $18-33$ & $0.52 \pm 0.3$ & $0.53 \pm 0.1$ & $0.23 \pm 0.06$ \\
\hline
\end{tabular}

${ }^{a}$ Sample locations are shown on Fig. 5.

The first samples (A) from the hole $(\sim 0$ to $15 \mathrm{~cm})$ were concrete core plugs, which were returned to the hole.

Tndicated counting error is at the $95 \%$ confidence level $( \pm 2 \sigma)$.

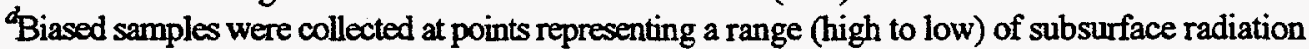
levels as indicated by surface FIDLER measurements. No systematic soil samples were collected. 
Table 4. Transferable alpha and beta-gamma measurements at Building 31, former Linde Uranium Refinery, Tonawanda, New York

\begin{tabular}{|c|c|c|c|c|}
\hline \multirow{2}{*}{$\begin{array}{l}\text { Smear } \\
\text { sample } \\
\mathbb{D}^{a}\end{array}$} & \multirow{2}{*}{ Location $^{a}$} & \multirow{2}{*}{$\begin{array}{l}\text { Date smear } \\
\text { collected }\end{array}$} & \multicolumn{2}{|c|}{$\begin{array}{c}\text { Removable radioactivity } \\
\text { (smears) }\end{array}$} \\
\hline & & & $\begin{array}{c}\text { Alpha } \\
\left(\mathrm{dpm} / 100 \mathrm{~cm}^{2}\right)\end{array}$ & $\begin{array}{l}\text { Beta-gamma } \\
\left(\mathrm{dpm} / 100 \mathrm{~cm}^{2}\right)\end{array}$ \\
\hline \multicolumn{5}{|c|}{ First floor } \\
\hline VT6 & $\begin{array}{l}15.3 \mathrm{~N}, 15 \mathrm{E} \\
\text { Room } 110 \text {, open bay, } \\
\text { underside of beam }\end{array}$ & $12-16-95$ & {$[0]$} & {$[-18]$} \\
\hline VT7 & $\begin{array}{l}16.5 \mathrm{~N}, 25 \mathrm{E} \\
\text { Room } 110 \text {, open bay, } \\
\text { overhead }\end{array}$ & $12-16-95$ & [1] & {$[24]$} \\
\hline VT8 & $\begin{array}{l}20.5 \mathrm{~N}, 18 \mathrm{E} \\
\text { Room } 110 \text {, open bay, } \\
\text { ceiling vent housing }\end{array}$ & $12-16-95$ & [2] & {$[-35]$} \\
\hline VT9 & $\begin{array}{l}33.4 \mathrm{~N}, 15 \mathrm{E} \\
\text { Room } 110 \text {, open bay, } \\
\text { I-beam }\end{array}$ & $12-16-95$ & {$[1]$} & {$[6]$} \\
\hline VT10 & $\begin{array}{l}32.4 \mathrm{~N}, 24 \mathrm{E} \\
\text { Room } 110 \text {, open bay, } \\
\text { overhead beam }\end{array}$ & $12-16-95$ & {$[0]$} & {$[-18]$} \\
\hline VT11 & $\begin{array}{l}43.4 \mathrm{~N}, 18 \mathrm{E} \\
\text { Room } 110 \text {, open bay, } \\
\text { N-S I-beam }\end{array}$ & $12-16-95$ & [2] & {$[53]$} \\
\hline VT22 & $\begin{array}{l}12.7 \mathrm{~N}, 35.6 \mathrm{E} \\
\text { Room } 111 \text {, overhead }\end{array}$ & $12-17-95$ & [0] & {$[-6]$} \\
\hline VT23 & $\begin{array}{l}29 \mathrm{~N}, 53 \mathrm{E} \\
\text { Room 111, overhead }\end{array}$ & $12-17-95$ & {$[0]$} & {$[-59]$} \\
\hline VT24 & $\begin{array}{l}24 \mathrm{~N}, 40 \mathrm{E} \\
\text { Room } 111 \text {, overhead }\end{array}$ & $12-17-95$ & {$[0]$} & {$[12]$} \\
\hline \multicolumn{5}{|c|}{ Second Floor } \\
\hline VT1 & $\begin{array}{l}0.0 \mathrm{~N}, 3.1 \mathrm{E} \\
\text { Room 203, ceiling }\end{array}$ & $11-2-95$ & $100^{d}$ & $220^{\mathrm{d}}$ \\
\hline
\end{tabular}


Table 4 (continued)

\begin{tabular}{|c|c|c|c|c|}
\hline \multirow{2}{*}{$\begin{array}{l}\text { Smear } \\
\text { sample } \\
\mathrm{ID}^{a}\end{array}$} & \multirow{2}{*}{ Location $^{a}$} & \multirow{2}{*}{$\begin{array}{l}\text { Date smear } \\
\text { collected }\end{array}$} & \multicolumn{2}{|c|}{$\begin{array}{l}\text { Removable radioactivity } \\
\text { (smears) }\end{array}$} \\
\hline & & & $\begin{array}{c}\text { Alpha }^{b} \\
\left(\mathrm{dpm} / 100 \mathrm{~cm}^{2}\right)\end{array}$ & $\begin{array}{l}\text { Beta-gamma } \\
\left(\mathrm{dpm} / 100 \mathrm{~cm}^{2}\right)\end{array}$ \\
\hline VT2 & $\begin{array}{l}1.5 \mathrm{~N}, 4.0 \mathrm{E} \\
\text { Room 203, ceiling }\end{array}$ & $11-2-95$ & $33^{d}$ & [12] \\
\hline VT3 & $\begin{array}{l}\text { 18.5N, } 7.75 \mathrm{E} \\
\text { Room 207, ceiling }\end{array}$ & $11-2-95$ & $65^{d}$ & [100] \\
\hline VT4 & $\begin{array}{l}15.4 \mathrm{~N}, 9.25 \mathrm{E} \\
\text { Room 207, ceiling }\end{array}$ & $11-2-95$ & [3] & [0] \\
\hline VT5 & $\begin{array}{l}3.7 \mathrm{~N}, 9.5 \mathrm{E} \\
\text { Room } 205 \text {, overhead }\end{array}$ & $11-15-95$ & $14^{e}$ & [89] \\
\hline VT12 & $\begin{array}{l}33 \mathrm{~N}, 2 \mathrm{E} \\
\text { Room } 215 \text {, under floor } \\
\text { tile }\end{array}$ & $12-17-95$ & $11^{e}$ & {$[-35]$} \\
\hline VT13 & $\begin{array}{l}32.5 \mathrm{~N}, 2.5 \mathrm{E} \\
\text { Room } 215 \text {, ceiling }\end{array}$ & $12-17-95$ & [0] & {$[-12]$} \\
\hline VT14 & $\begin{array}{l}\text { IN, } 1 E \\
\text { Room 203, floor }\end{array}$ & $12-17-95$ & {$[0]$} & {$[-6]$} \\
\hline VT15 & $\begin{array}{l}6.6 \mathrm{~N}, 1.5 \mathrm{E} \\
\text { Room 201, floor }\end{array}$ & $12-17-95$ & {$[0]$} & {$[-12]$} \\
\hline VT16 & $\begin{array}{l}6.5 \mathrm{~N}, 2.5 \mathrm{E} \\
\text { Room 201, ceiling }\end{array}$ & $12-17-95$ & [6] & {$[-18]$} \\
\hline VT17 & $\begin{array}{l}9 \mathrm{~N}, 10 \mathrm{E} \\
\text { Room 202, floor }\end{array}$ & $12-17-95$ & [0] & {$[-59]$} \\
\hline VT18 & $\begin{array}{l}\text { 8N, 9E } \\
\text { Room 202, ceiling }\end{array}$ & $12-17-95$ & $12^{e}$ & {$[18]$} \\
\hline VT19 & $\begin{array}{l}13 \mathrm{~N}, 4.3 \mathrm{E} \\
\text { hallway overhead } \\
\text { bridging }\end{array}$ & $12-17-95$ & $37^{d}$ & [24] \\
\hline
\end{tabular}


Table 4 (continued)

\begin{tabular}{|c|c|c|c|c|}
\hline \multirow{2}{*}{$\begin{array}{l}\text { Smear } \\
\text { sample } \\
\mathrm{ID}^{a}\end{array}$} & \multirow{2}{*}{ Location $^{a}$} & \multirow{2}{*}{$\begin{array}{l}\text { Date smear } \\
\text { collected }\end{array}$} & \multicolumn{2}{|c|}{$\begin{array}{c}\text { Removable radioactivity } \\
\text { (smears) }\end{array}$} \\
\hline & & & $\begin{array}{c}\text { Alpha } \\
\left(\mathrm{dpm} / 100 \mathrm{~cm}^{2}\right)\end{array}$ & $\begin{array}{l}\text { Beta-gamma } \\
\left(\text { dpm } / 100 \mathrm{~cm}^{2}\right)\end{array}$ \\
\hline VT20 & $\begin{array}{l}13 \mathrm{~N}, 4.3 \mathrm{E} \\
\text { hallway floor }\end{array}$ & $12-17-95$ & {$[0]$} & {$[-12]$} \\
\hline VT21 & $\begin{array}{l}23.5 \mathrm{~N}, 10.5 \mathrm{E} \\
\text { hallway ceiling }\end{array}$ & $12-17-95$ & {$[0]$} & {$[0]$} \\
\hline
\end{tabular}

${ }^{a}$ Sample locations are shown on Fig. 6 (first floor) and Fig. 7 (second floor).

MDA for alpha activity $=9 \mathrm{dpm} / 100 \mathrm{~cm}^{2}$.

MDA for beta activity $=-125 \mathrm{dpm} / 100 \mathrm{~cm}^{2}$.

${ }^{d}$ Area not verified below guidelines on this date (See Table 5).

'Below guidelines (See Table 1).

Note: All values represent the actual measurement less the background response of the detector used. A value in brackets [\#] indicates that the measurement was not discernable from the background response of the detector ( $95 \%$ confidence). 


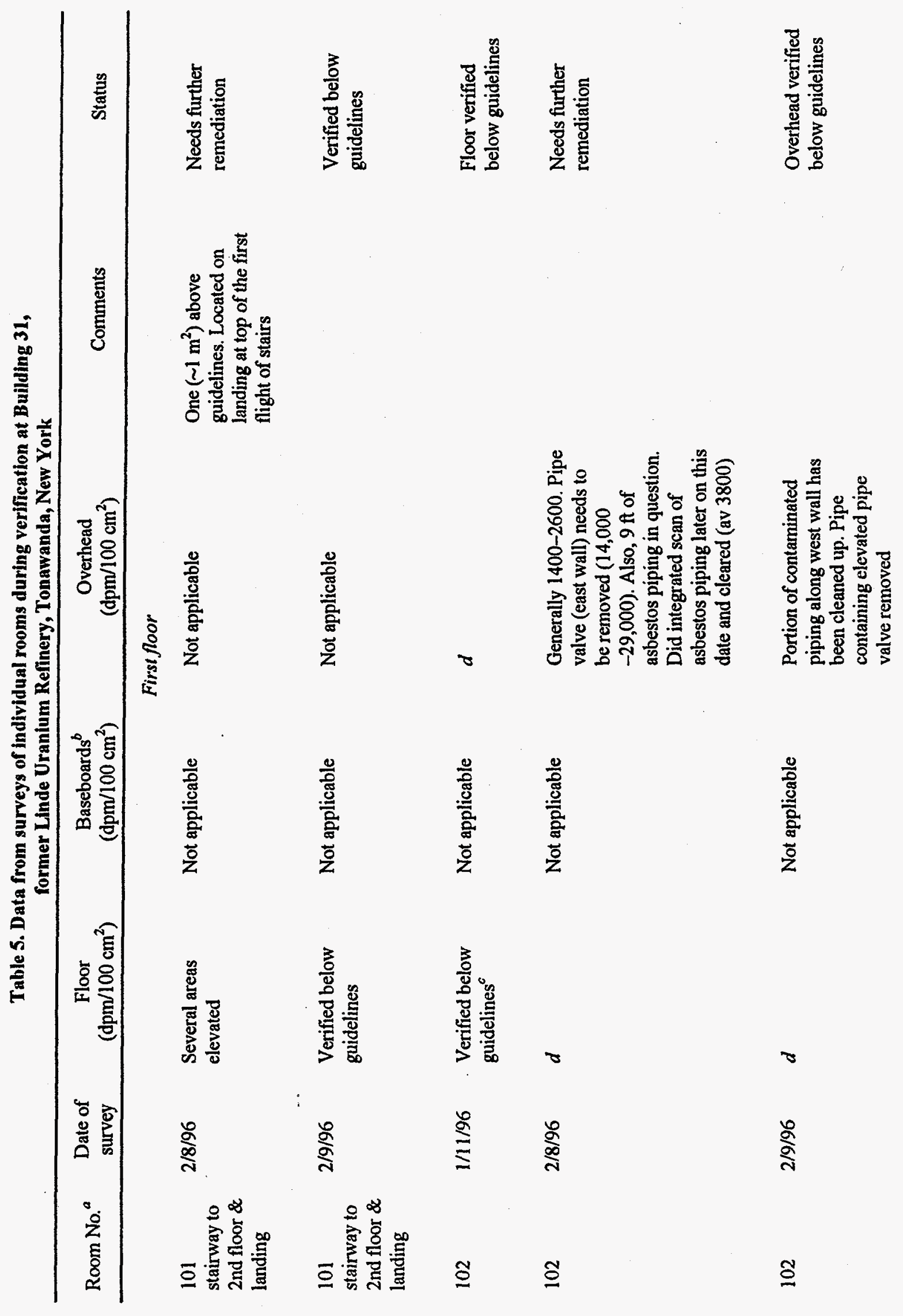




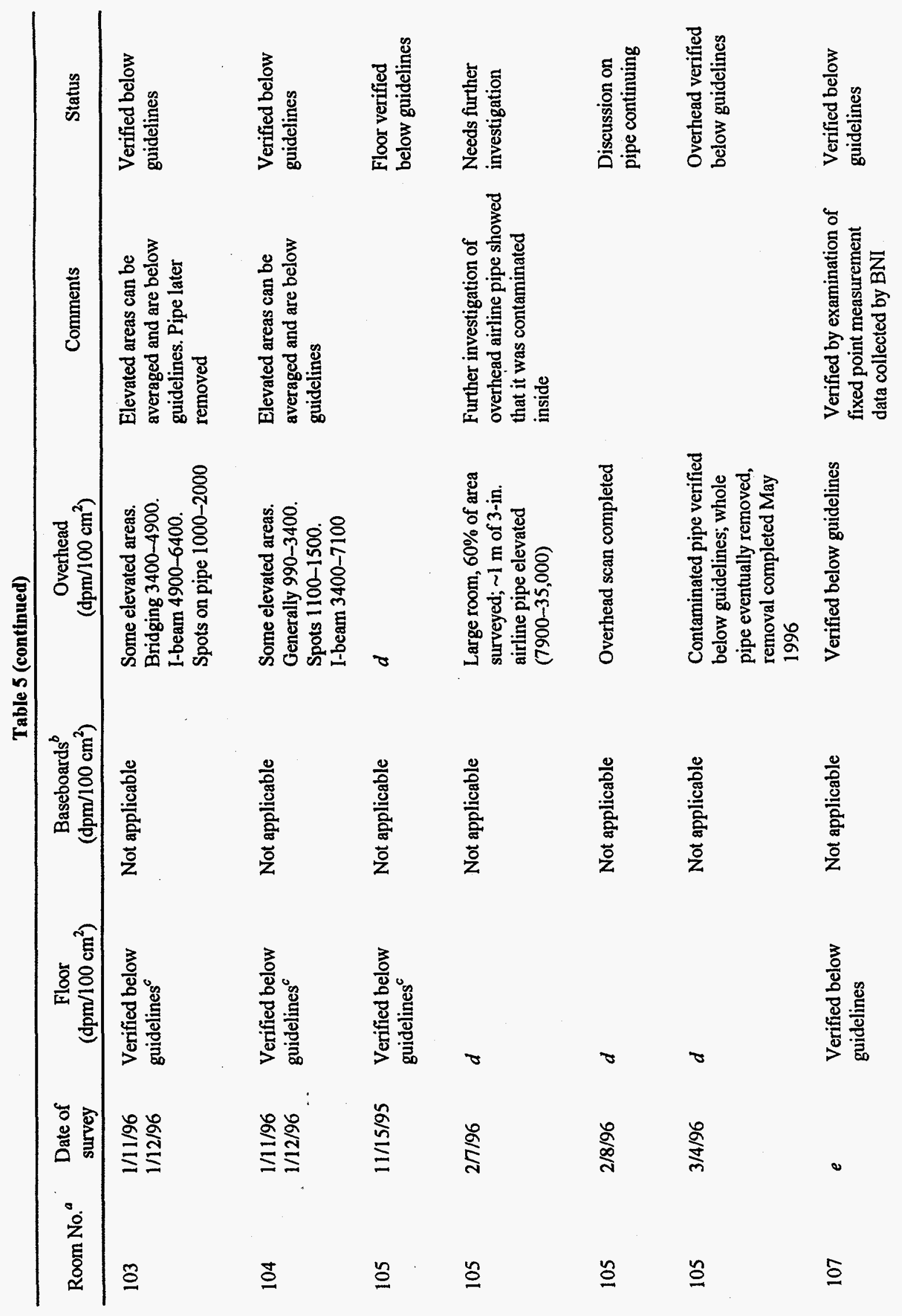




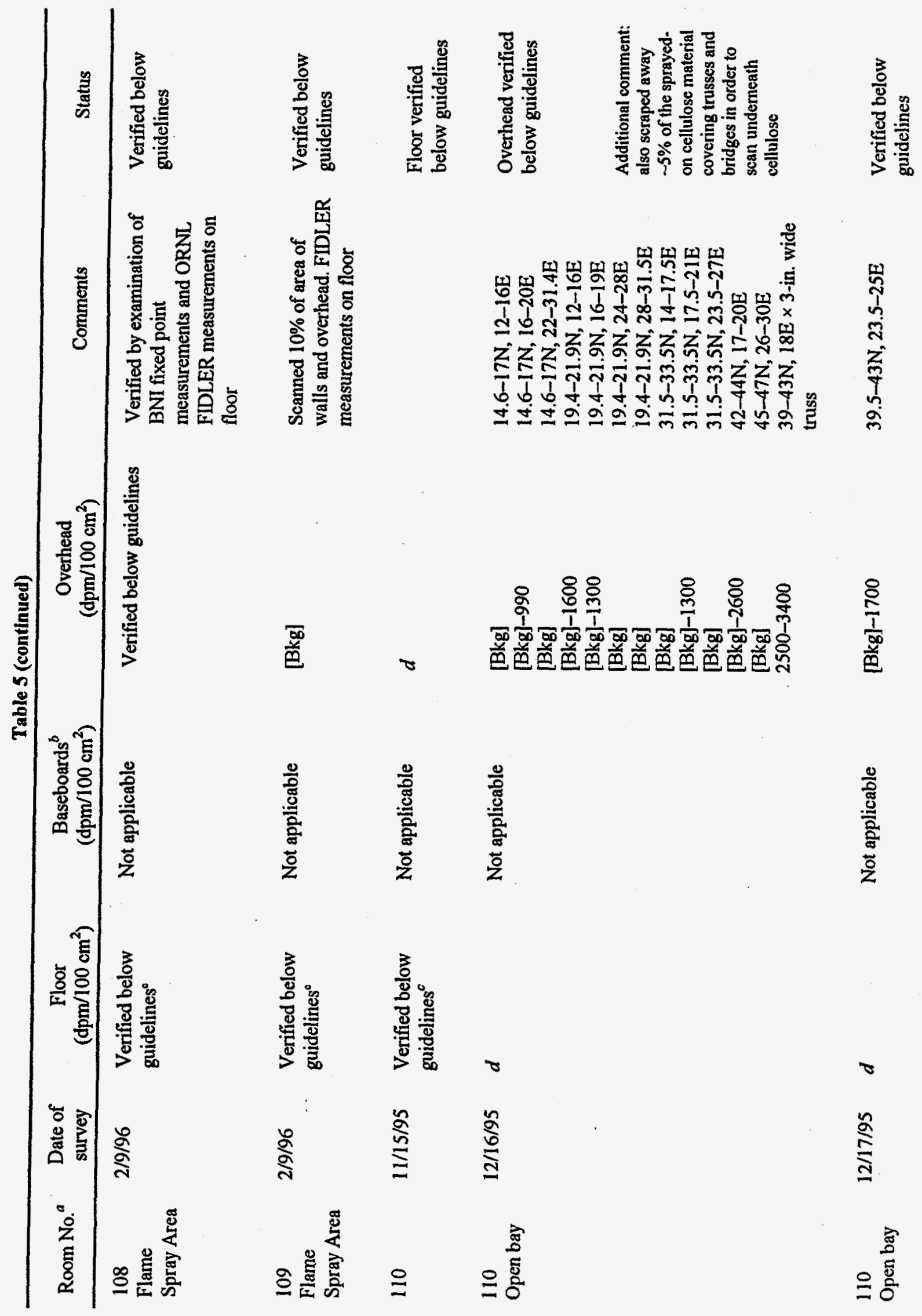




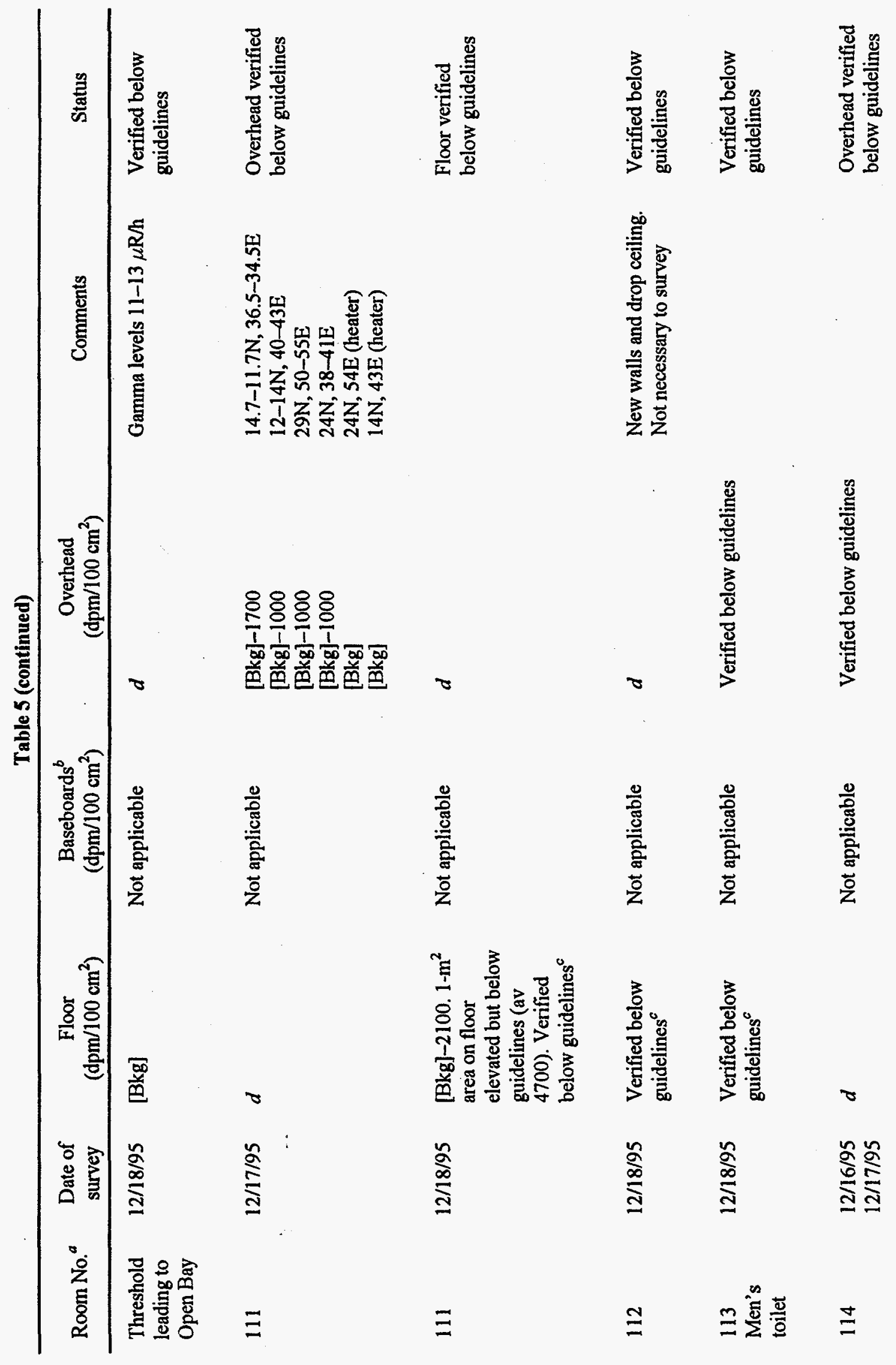




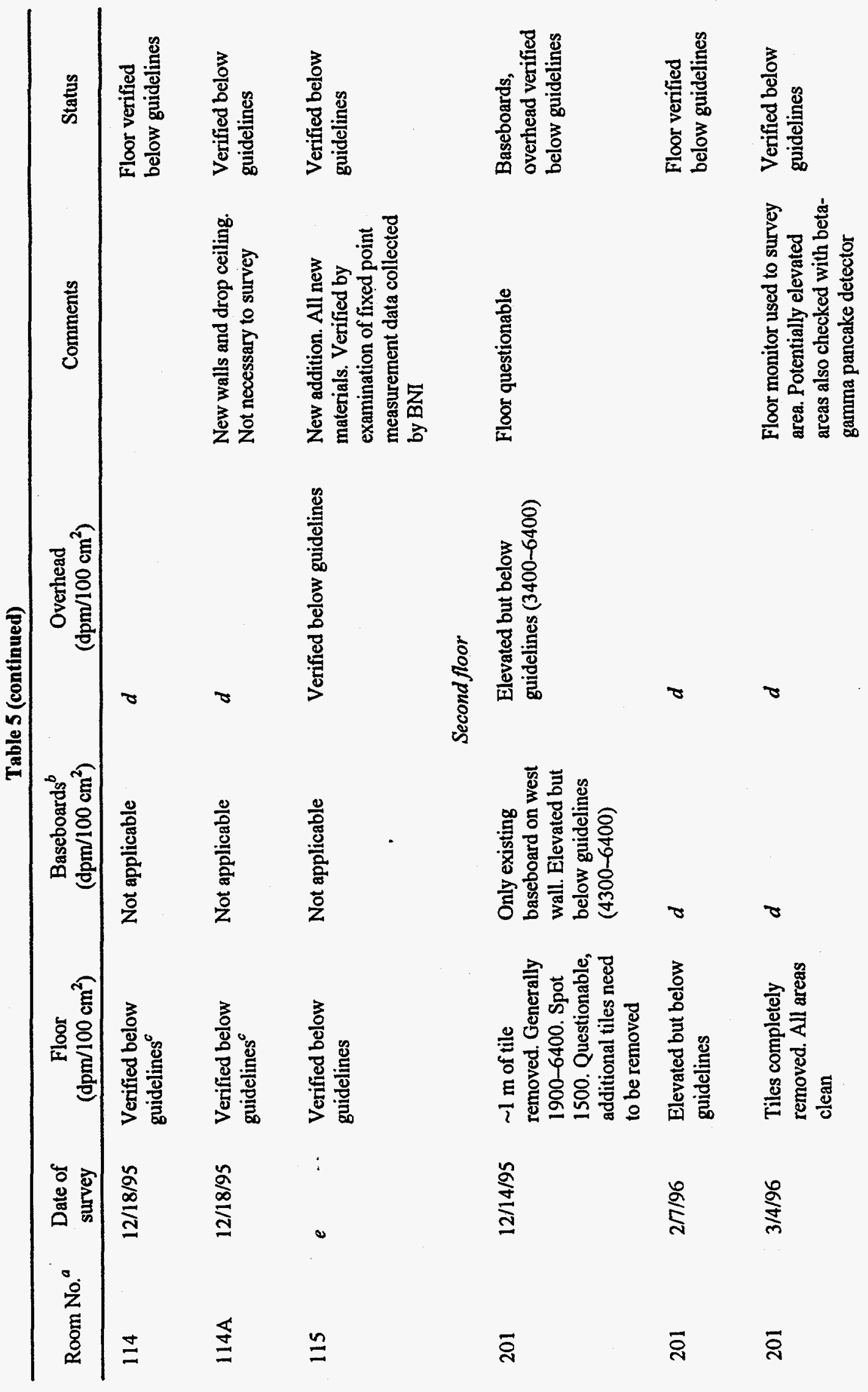




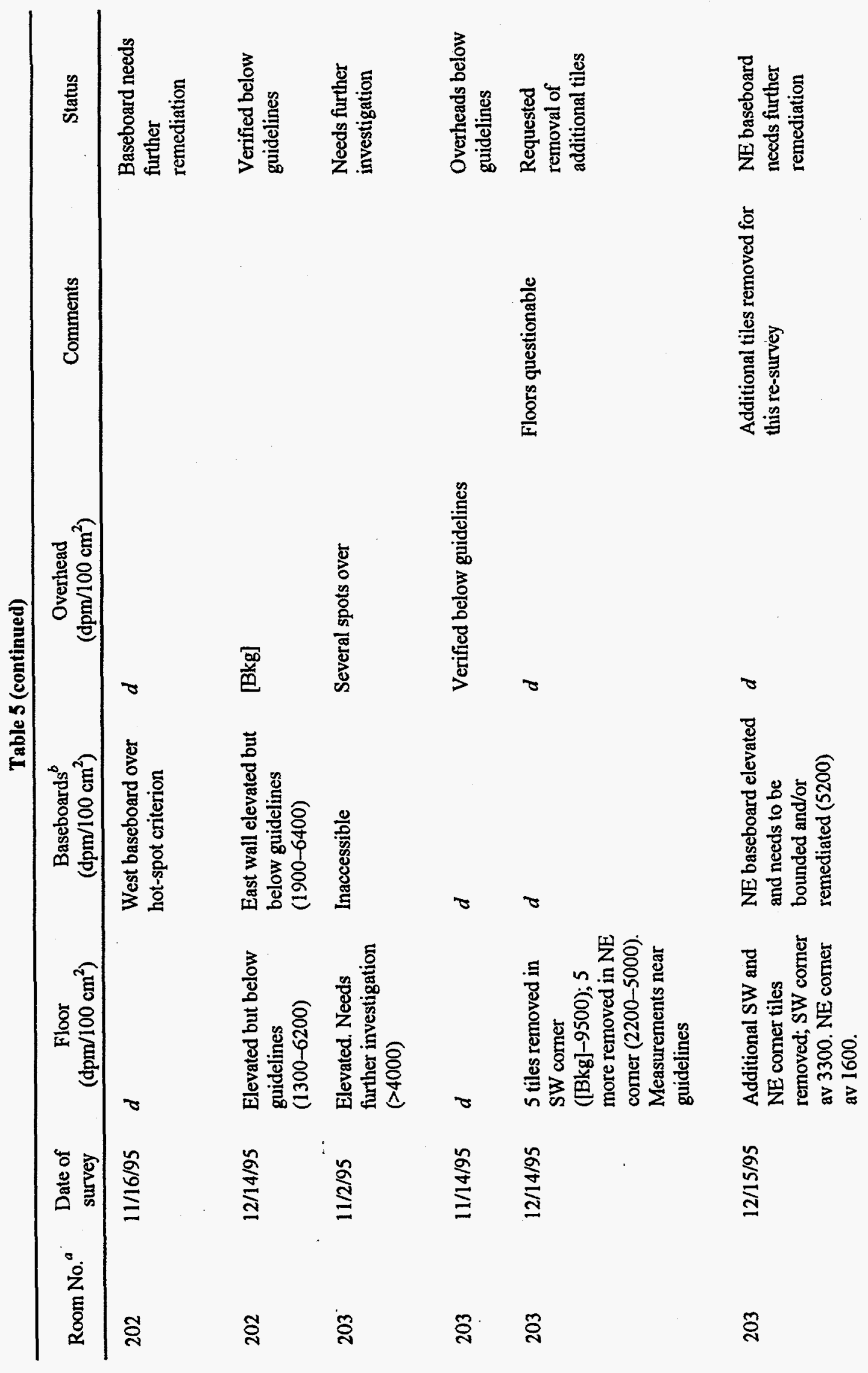




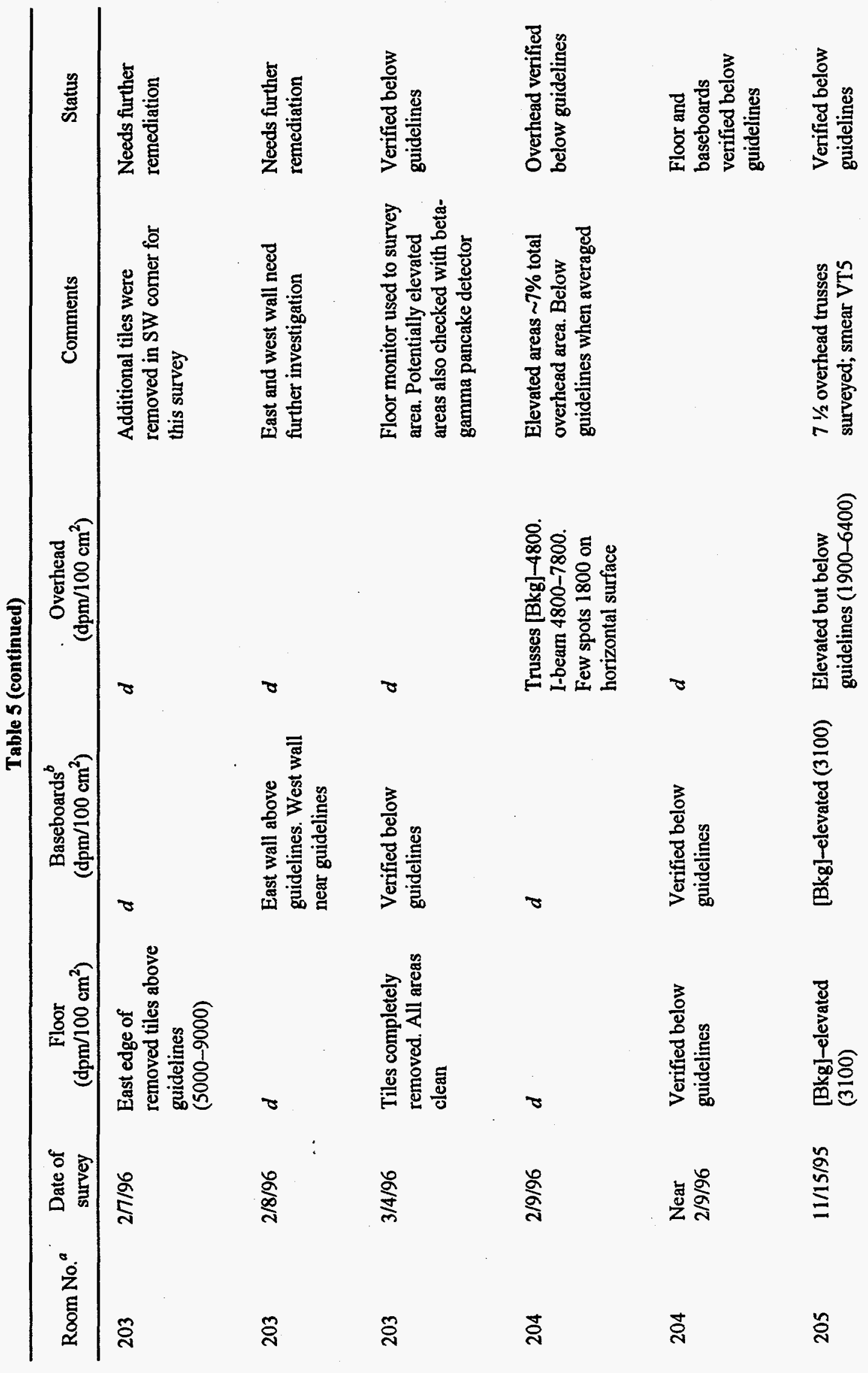




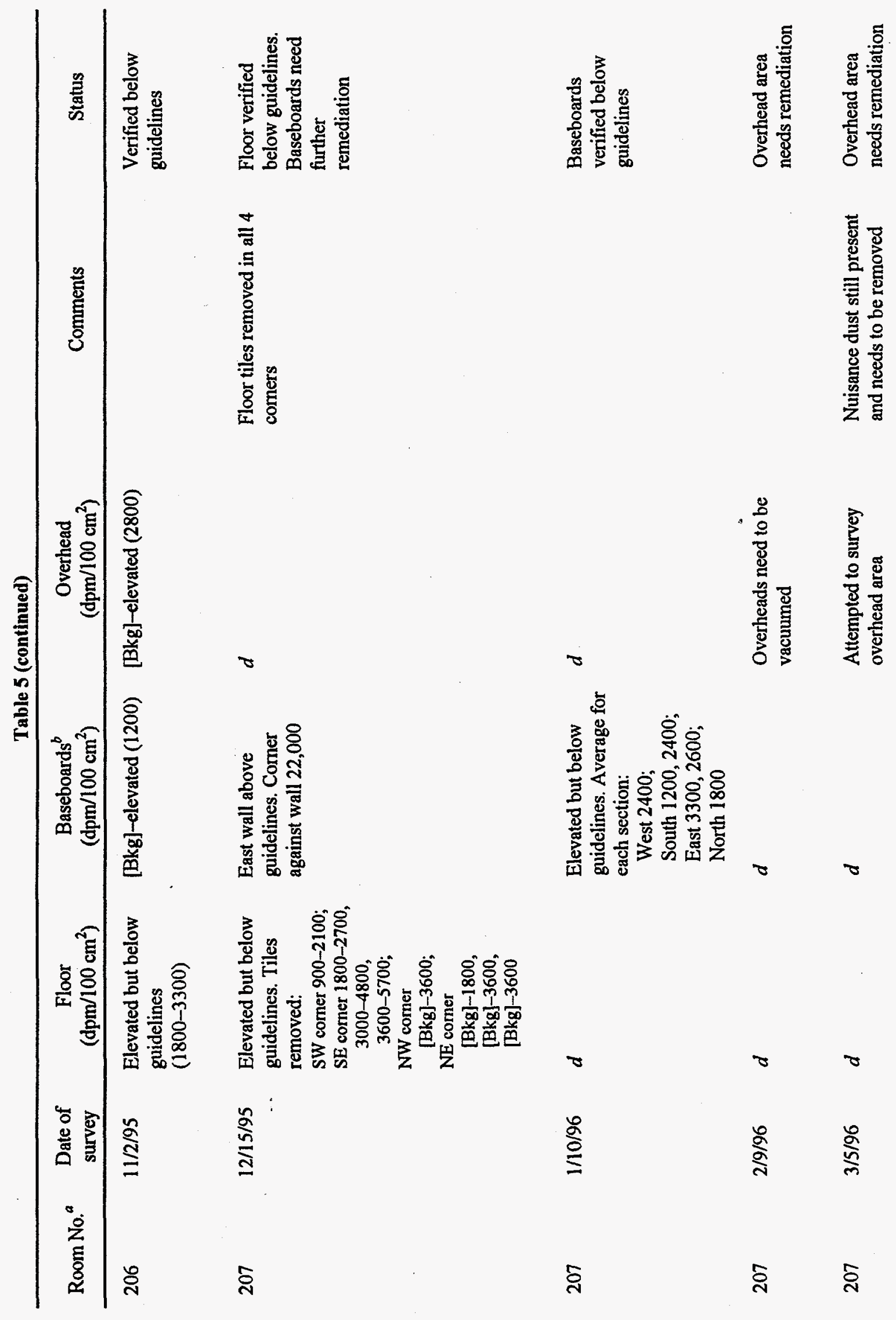




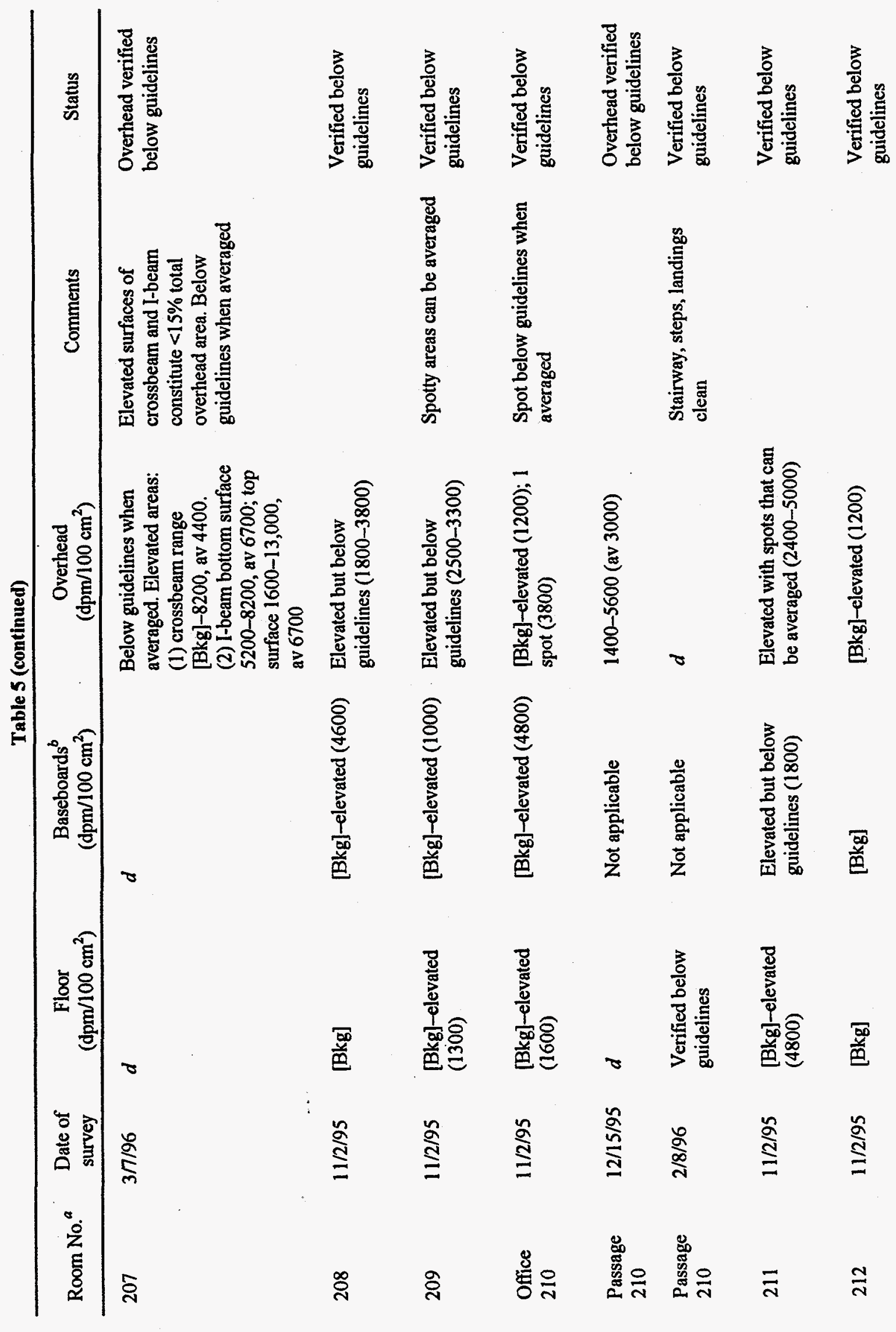




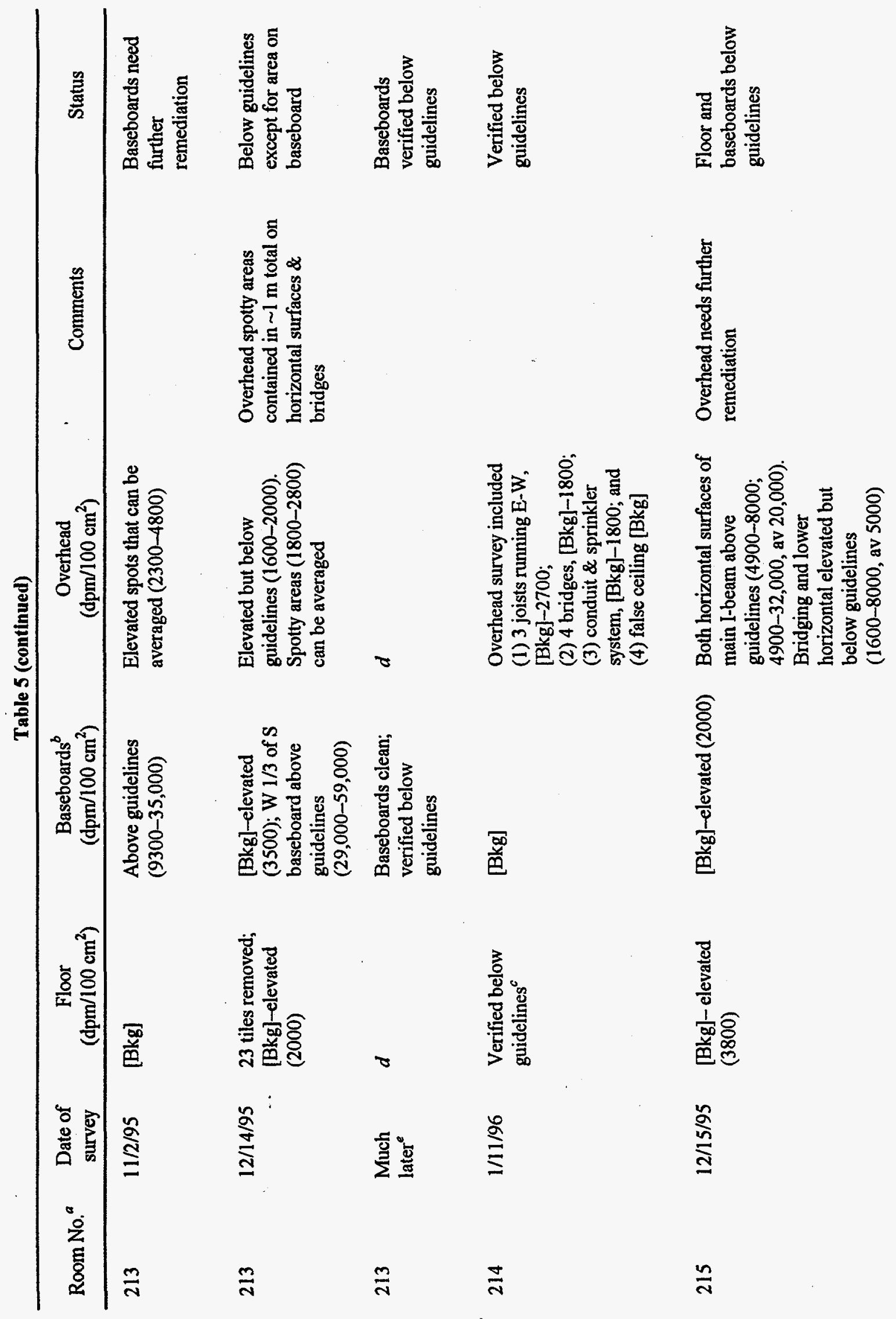




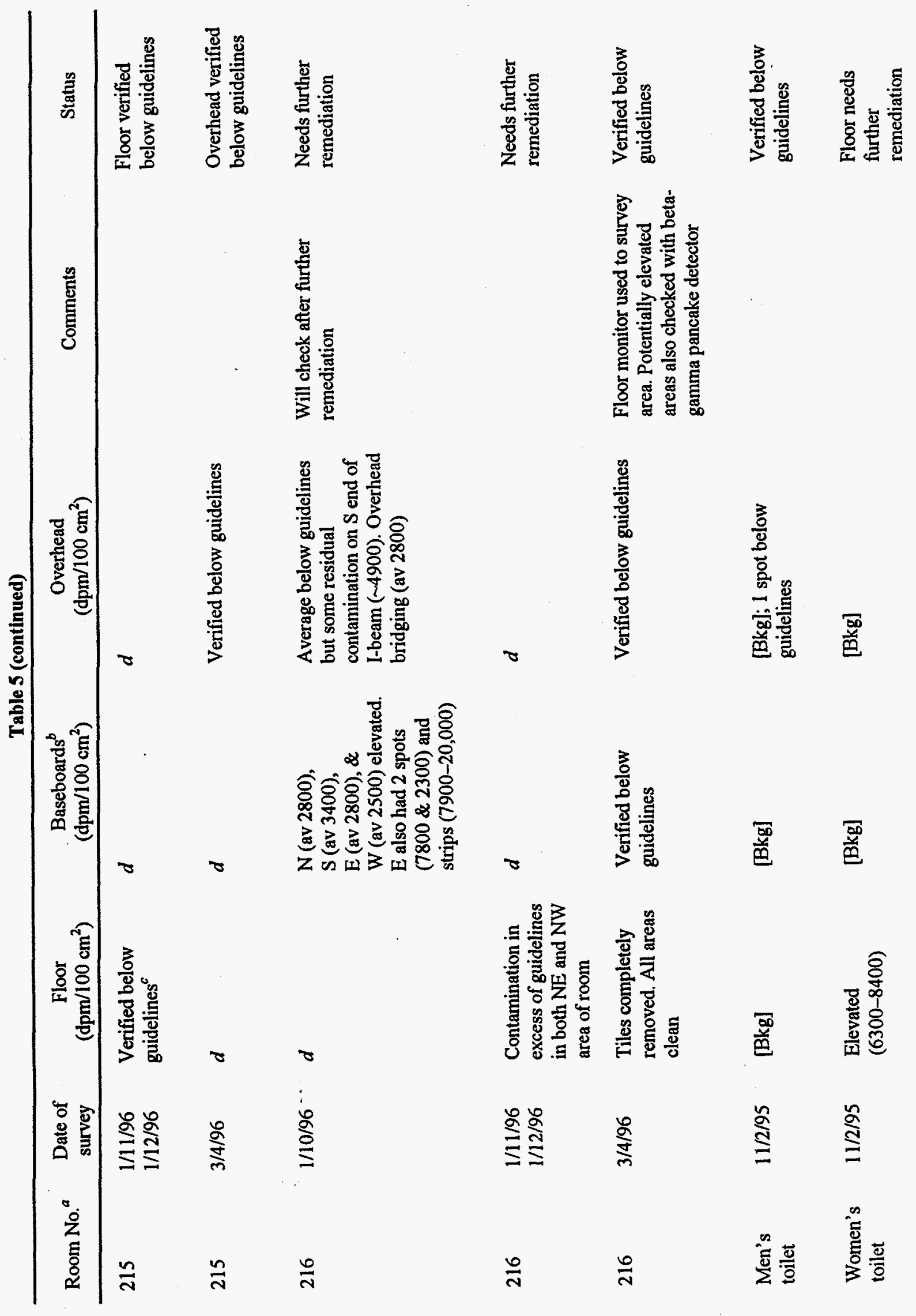




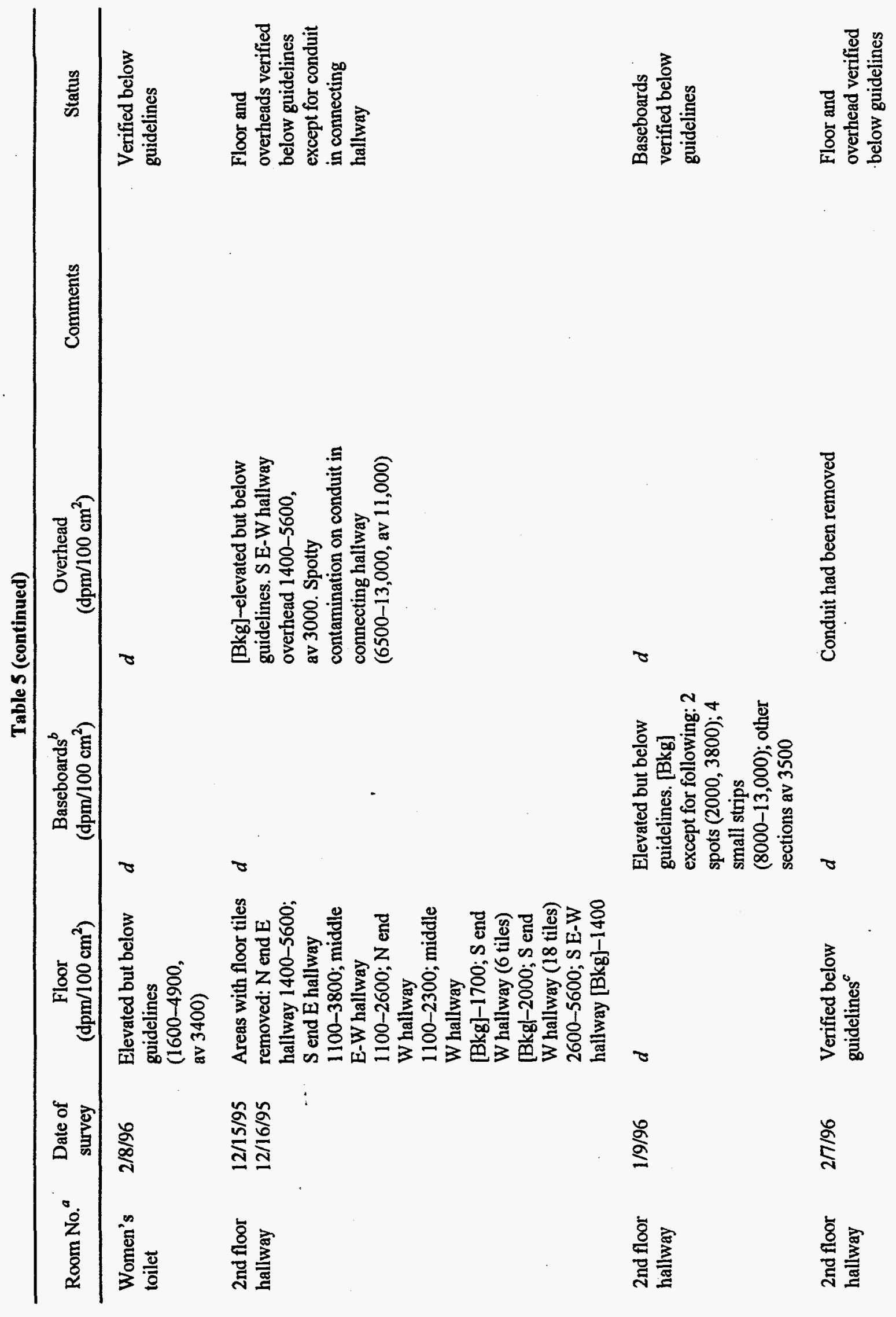




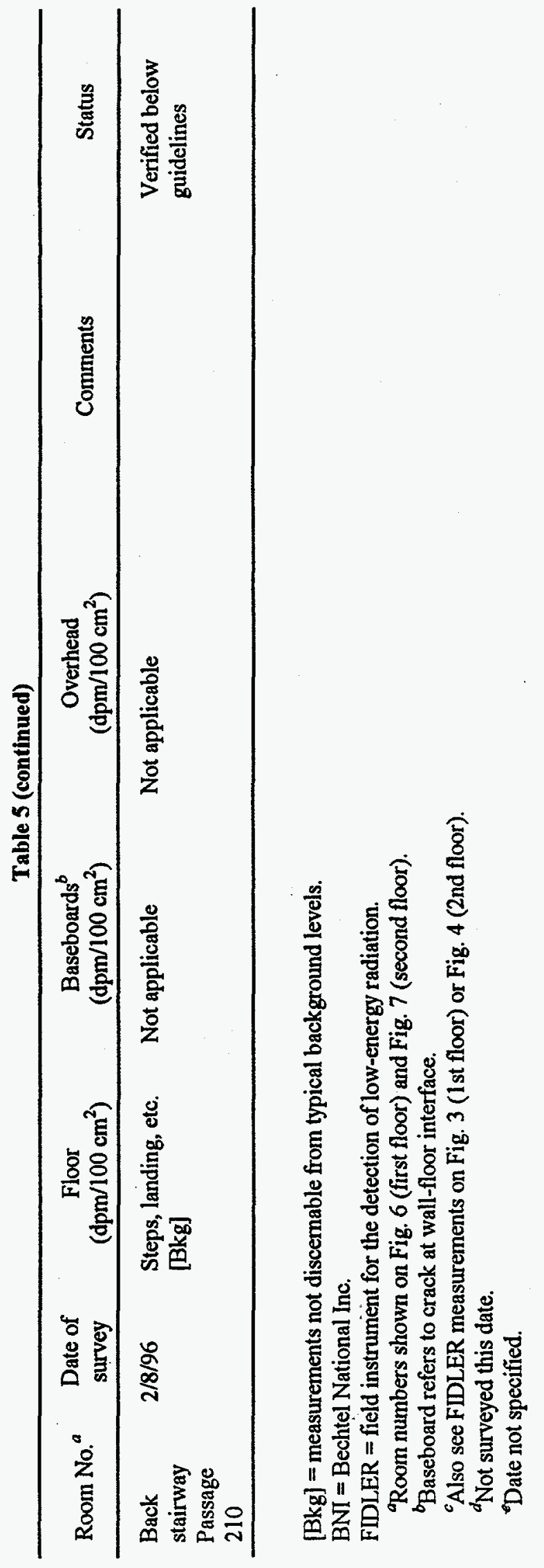




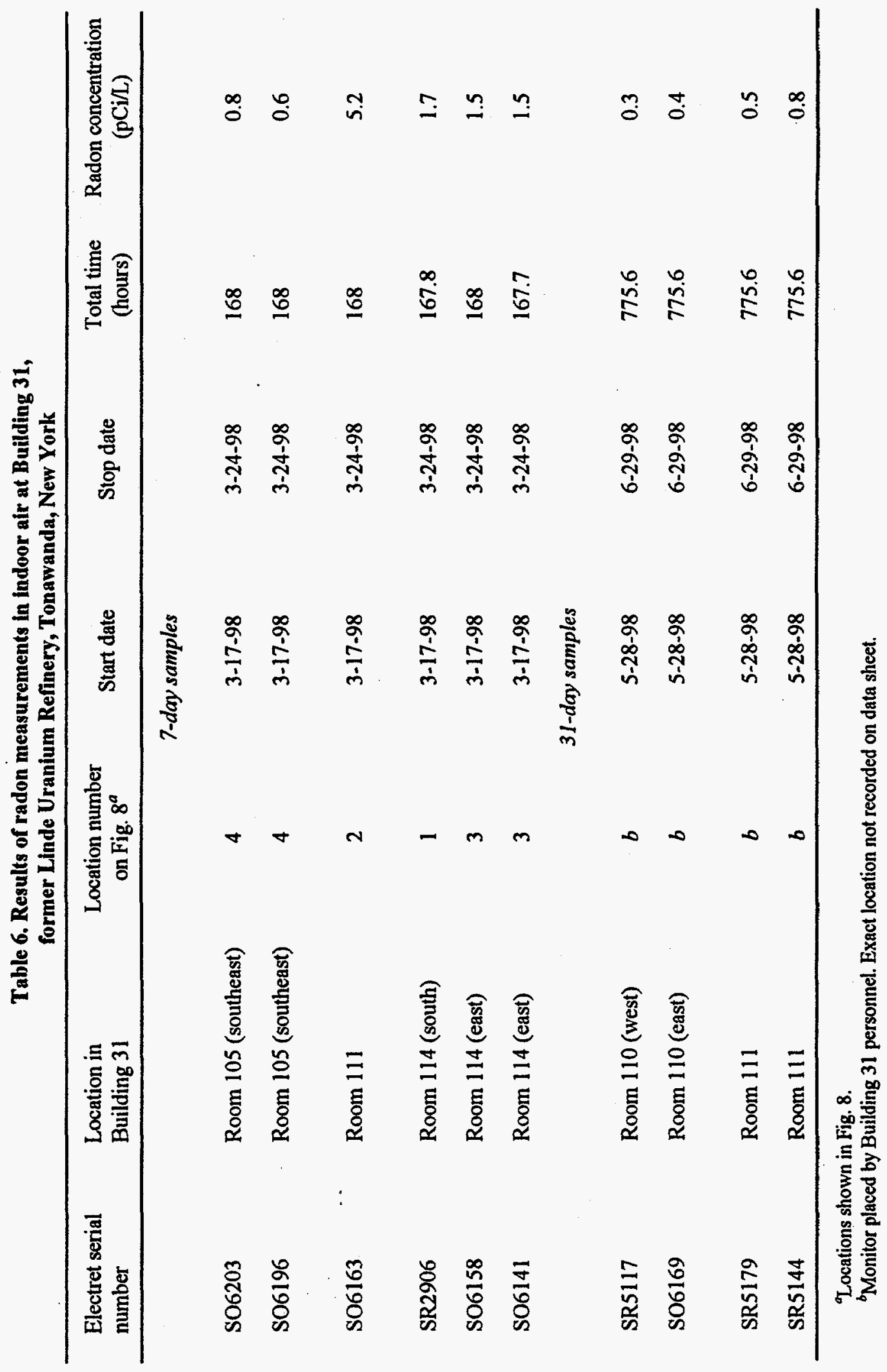


ORNL/RASA-96/10

\section{DISTRIBUTION}

1. K. J. Brown

2. R. D. Foley

3. R. C. Gosslee

4. C. A. Johnson

5-6. S. P. McKenzie

7. M. E. Murray

\author{
8. D. A. Roberts \\ 9. R. E. Rodriguez \\ 10. M. S. Uziel \\ 11-15. MAD Records Center \\ 16. Central Research Library \\ 17. Laboratory Records - RC
}

18. S. K Armit, Bechtel National, Inc., FUSRAP Department, Oak Ridge Corporate Center, 151 Lafayette Drive, P.O. Box 350, Oak Ridge, TN 37831-0350

19. W. L. Beck, ORISE, E/ESD, 1299 Bethel Valley Road, Oak Ridge, TN 37830-8007

20. R. J. Gibbs, Bechtel National Inc., 70 Pearce Avenue, Tonawanda, NY 14150-6711

21-30. Raymond. L. Pilon, CELRB-PP-PM, U.S. Army Corps of Engineers, 1776 Niagara Street, Buffalo, NY 14207-3111

31-32. Office of Scientific and Technical Information, U.S. Department of Energy, P.O. Box 62, Oak Ridge, TN 37831-0062 